\title{
Structural Diversity of Organic Contaminants in a meso-scaled River System
}

\author{
Christina A. Schwanen • Jan Schwarzbauer
}

Received: 8 September 2021 / Accepted: 5 January 2022 / Published online: 17 January 2022

(C) The Author(s) 2022

\begin{abstract}
Due to intensive anthropogenic usage, a complex mixture of inorganic and organic contaminants entered and still enters freshwater systems, released by various activities and emission sources. However, because of the highly dynamic nature of rivers, the individual occurrence, fate, and behavior, especially of organic contaminants, are highly complex and not fully understood. Here, a GC/MS nontarget screening was applied to identify and determine the chemical diversity in the aqueous phase of the meso-scaled Rur river and to categorize indicative and relevant contaminants according to their load profiles for a distinct emission characteristic. Besides very well-known or widespread lipophilic to semi-polar contaminants, also so far unknown or only sporadically identified substances have been detected. In particular, wastewater treatment plants and the paper industry have been identified as major emission sources. Additionally, temporal variations in organic contamination were investigated over three sampling campaigns (2004, 2015, and 2020). Within this timespan, the overall composition of the
\end{abstract}

Supplementary Information The online version contains supplementary material available at https://doi. org/10.1007/s11270-022-05503-1.

C. A. Schwanen · J. Schwarzbauer $(\bowtie)$

Institute of Geology and Geochemistry of Petroleum

and Coal, RWTH Aachen University, Lochnerstrasse 4-20,

52056 Aachen, Germany

e-mail: jan.schwarzbauer@emr.rwth-aachen.de contamination in the Rur has changed slightly, but nevertheless, the high chemical diversity remained. A detailed consideration such as that undertaken in this study is necessary as the occurrence of substances in a river system depends on many different factors. For a holistic assessment of environmental behavior, not only the sampling locations and associated development of emission profiles must be considered but also temporal variations and mitigation measures. Such a multi-parameter scenario provides an important basis for the mitigation and reduction of organic pollutants in our environment.

Keywords GC/MS non-target screening · Pollution pattern $\cdot$ River water $\cdot$ Organic contaminants $\cdot$ Fluvial transport

\section{Introduction}

Particularly in the twentieth century, anthropogenic activities such as changing of watercourses, increasing pollution, and thus, rapid degradation impacted the river systems worldwide (e.g., Dsikowitzky et al., 2004a, b; Lin et al., 2017; Wang et al., 2012). Due to the highly dynamic nature of rivers, a complex mixture of inorganic and organic contaminants entered and still enters freshwater systems, released by various activities and emission sources (Lin et al., 2017; Schwarzbauer, 2006). As a first rough classification, the sources of anthropogenic contaminants can be 
divided into point sources (industrial and municipal effluents, single incidents as, e.g., industrial disasters) and diffuse sources (agricultural or shipping activities), leading to direct respectively indirect contamination of freshwater systems (Heim \& Schwarzbauer, 2013; Morin-Crini et al., 2021; Petrovic et al., 2016).

Low-molecular-weight organic contaminants are used for various purposes in industry and urban applications (e.g., as pesticides, plasticizers, or pharmaceuticals) so that they show an extremely high diversity and structural variety (Bernhardt et al., 2017; Botalova et al., 2009; Lorenzo et al., 2018). Depending on their chemical and physical behavior and the dynamic nature in this compartment, the distribution processes in the aqueous phase are very short-term and complex, which makes their determination quite challenging. Only a few substances (like PCBs, PAHs, or DDT) and their environmental behavior in water systems are already well studied (e.g., Cerniglia, 1993; Safe, 1994; Turusov et al., 2002; Zhang et al., 2007). But mostly specific fates and complex behaviors are still largely unexplored, posing unknown risks to ecosystems and water safety.

This is of raising concern as surface waters are largely used as drinking water and human beings are thus highly interested in their respective conditioning and protection (Benotti et al., 2009; Houtman, 2010; Petrovic, 2003; Schwarzbauer, 2006; Vulliet et al., 2011). For instance, in North Rhine-Westphalia (Germany), around $60 \%$ of the raw water for drinking is taken from surface waters (esp. from dams), bank filtrate, and enriched groundwater (IT.NRW, 2019).

Furthermore, even though wastewater treatment involves increasingly efficient processes, and policy and environmental legislation are focusing more and more on water protection and renaturation, new, unknown pollutants are still entering the environment (Morin-Crini et al., 2021; Petrovic et al., 2016). Our existing conventional treatment plants are not designed to eliminate these "emerging contaminants," and there are currently no regulations regarding monitoring or public reporting of their presence in water supply and effluents (e.g., Lorenzo et al., 2018; Mohapatra \& Kirpalani, 2019; Patel et al., 2019; Tang et al., 2019).

To determine the behavior and fate of contaminants and for risk assessment, it is therefore crucial to be able to assign identified substances to possible sources. Thus, especially dynamic and rather small river systems are well suited to show the general environmental behavior. Individual distribution processes, influences of anthropogenic measures, as well as resulting impacts on the ecosystem are easier to identify and differentiate. In contrast, in larger river systems such as the Rhine, complex mixtures of pollutants are often identified, resulting in a cumulative detection over the entire course of the river (Ruff et al., 2015; Schäfer et al., 2011). In this study, the Rur river as a meso-scaled catchment system was chosen to assess the longitudinal contamination status of the river water. Within this river system, heterogeneous emission sources as industrial and municipal wastewater effluents can be identified and considered. This also enables transferability to other river systems.

Up to now, only a few comparable studies are available regarding, for example, the Lippe river in Germany (Dsikowitzky et al., 2004a, b) or the Turia and Henares rivers in Spain (Ccanccapa-Cartagena et al., 2019; Gómez et al., 2012). These studies involved extensive screening and detection of a variety of organic substances in a diverse but distinguishable emission situation. However, the timeframe investigated is usually very limited and does not fully cover temporal developments. Schwarzbauer and Ricking (2010) investigated several different-sized European rivers to show the high structural diversity of organic contaminants. As part of their studies, they have also revealed that each river has unique contamination patterns and structures. Especially river-specific contaminants are promising candidates for monitoring programs. Thus, individual and fundamental investigations of single freshwater systems, as in this study, are a crucial precondition.

Consequently, the overall aim of the present study was to determine the chemical diversity of organic contaminants in the Rur river system regarding its aqueous phase. This river system can be considered as a typical and representative meso-scaled Central European catchment in terms of flow and emission sources. In general, as the inventory in the aqueous compartment is very dynamic, the determination of the distribution and fate of various substances is challenging. However, it is indispensable to fill the general lack of knowledge of the behavior of organic pollutants in complex environmental systems and their impact on corresponding ecosystems and freshwater resources. A gas chromatography-mass spectrometry 
(GC/MS) non-target screening was applied to identify both well-known organic pollutants and emerging contaminants as such screenings have been proven to be effective for the identification of various organic pollutants in aquatic systems (e.g., Grigoriadou \& Schwarzbauer, 2011; Köppe et al., 2020; Ruff et al., 2015; Schwarzbauer \& Ricking, 2010). Additionally, indicative and relevant contaminants are categorized according to their load profiles for a distinct emission characteristic. Furthermore, temporal variations in organic contamination between 2004, 2015, and 2020 were investigated to achieve a holistic assessment of emission sources and environmental fate and behavior of organic contaminants.

\section{Experimental}

\subsection{Study Area and Sampling}

The Rur river is a tributary to the superordinate river basin of the Meuse. In total, the Rur has a flow length of $163 \mathrm{~km}$ and covers a catchment area of about $2340 \mathrm{~km}^{2}$, so that it is classified as a meso-scaled catchment system. It can be divided into two geologic respectively physiographic parts: The southern part is the mountain range landscape of the Eifel that contributes to the Rhenish Massif, and the northern lowland part belongs to the Lower Rhine Embayment (Staatliches Umweltamt Aachen, 2005). The upper course of the Rur river is close to a natural state, whereby the transition to its middle course is determined by various dams and water reservoirs. These are partly used for drinking water supply, as, for example, the "Rurtalsperre" which is one of the largest reservoirs in Germany (Wasserverband Eifel-Rur, 2017a). The middle course, starting at Kreuzau (south of Düren), is clearly more urban and less natural. Particularly, the influence of local industry (paper, metal, and textile processing) and lignite mining are noteworthy here. From Linnich to its confluence with the Meuse at Roermond, it corresponds to a classic, but unnatural lowland watercourse, which is predominantly used for agricultural purposes.

In total, the river flows through three different countries (Belgium, Germany, and the Netherlands), showing a highly dynamic river course with multiple anthropogenic impacts. The most relevant discharges are considered to be two wastewater treatment plants
(WWTP) in the lower parts, the WWTP Düren and the WWTP Aachen-Soers (tributary Wurm) (Schröder, 1995; Schulze \& Matthies, 2001). Their treatments include municipal as well as industrial influents. However, overall, there are more than 40 WWTPs in the Rur catchment area influencing the river and its water quality (Wasserverband Eifel-Rur, 2017b).

Grab water samples $(1 \mathrm{~L})$ were collected at 21 locations on three different times over the entire course of the Rur river (as shown in Fig. 1). Not all localities could be sampled at all times. The width of the river is ranging from $2 \mathrm{~m}$ at the first sampling location to about 20 to $25 \mathrm{~m}$ at locations further downstream. Each water sample was scooped from midstream approximately $1 \mathrm{~m}$ below the water surface. The samples were filled into pre-cleaned glass flasks and sealed free of air bubbles. Prior to extraction, they were stored in the darkness at $4^{\circ} \mathrm{C}$. Samples were processed within 2 to 3 weeks after collection and then measured directly. The extraction and measurement procedure was the same for all sampling campaigns. The analysis of all datasets was extended in 2020/2021 to include further organic contaminants.

The first sampling campaign was performed from November 30 to December 2, 2004. The second sampling was done on March 23-24, 2015, and the third sampling was done on November 23-24, 2020. At the upstream sampling points, the mean flow over all sampling campaigns ranged from 1 to $4 \mathrm{~m}^{3} \mathrm{~s}^{-1}$, while further downstream, it increased to 9 to $27 \mathrm{~m}^{3} \mathrm{~s}^{-1}$.

\subsection{Chemicals, Blanks, and Recovery Experiments}

Only equipment made of glass, metal, and Teflon/ PTFE was used in the laboratory to minimize sample contamination. Prior to usage, the equipment was ultrasonically cleaned in detergent-containing water (Extran, Merck, Germany) and rinsed with highpurity acetone and $n$-hexane. All solvents used were acquired from Merck, Germany, and distilled over a $0.5 \mathrm{~m}$ packed column (reflux ratio approximately 1:25). The purity of the solvents was checked by gas chromatographic analyses. Anhydrous granulated sodium sulfate (Merck, Germany) and hydrochloric acid (Merck, Germany) required for the analytical procedure were cleaned with pure solvents. Blank analyses $(n=4)$ were carried out to determine possible background contaminations. They revealed the 

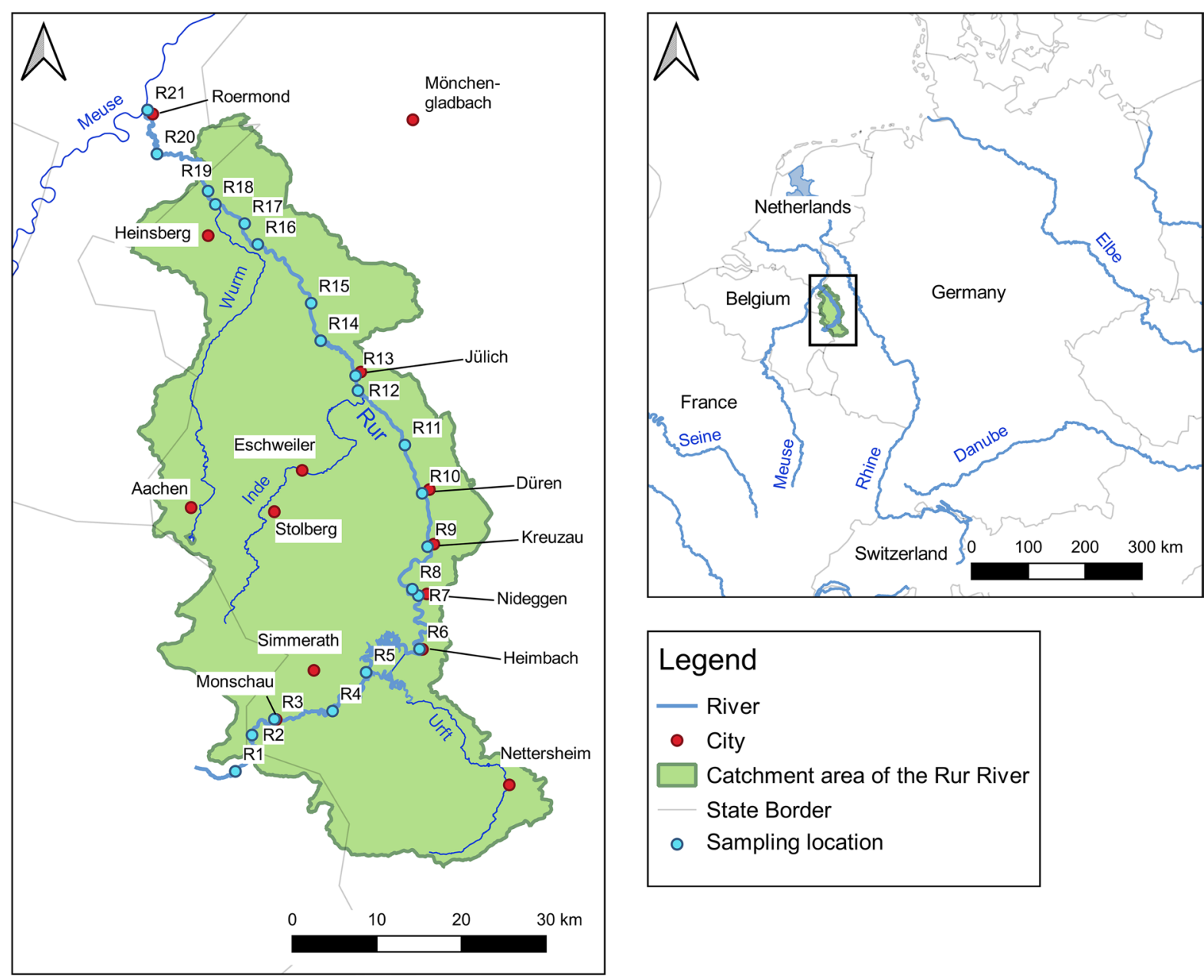

Fig. 1 Overview of the Rur catchment (North Rhine-Westphalia, Germany) and the location of the sampling sites R1 to R21

presence of different plasticizers as phthalates, acetyl tributylcitrate, and triacetin. Recovery rates $(n=4)$ were determined by spiking $1 \mathrm{~L}$ of high-purity water (Rotisolv, Roth, Germany) with $4 \mu \mathrm{g}$ of the respective reference compounds (Sigma-Aldrich, Germany) and then applying the same analytical procedure as described in the following for the environmental samples. The determined recovery rates are presented in Supplementary information.

\subsection{Sample Extraction}

Sample treatment and analysis followed well-established and previously described methods (e.g., Dsikowitzky et al., 2002; Grigoriadou et al., 2008). Prior to the extraction, the water samples were filtered through pre-cleaned GF/F filters (Macherey-Nagel, Düren, Germany) to remove suspended particulate matter from the aqueous phase. Afterwards, a liquid-liquid extraction was carried out to approximately $1 \mathrm{~L}$ samples. For this purpose, sequentially, $50 \mathrm{~mL}$ each of $n$-pentane (1st fraction), dichloromethane (2nd fraction), and dichloromethane after acidification to $\mathrm{pH} 2$ (3rd fraction) were used for the extraction in a separatory funnel. The sample was shaken for $5 \mathrm{~min}$ each, and after separation, fractions 1 and 2 were spiked with $50 \mu \mathrm{L}$ of a surrogate standard solution containing the reference compounds fluoroacetophenone $\left(5.8 \mathrm{ng} \mu \mathrm{L}^{-1}\right)$, benzophenone-d10 (6.3 $\left.n g \mathrm{~L}^{-1}\right)$, and hexadecane-d34 (6.0 $\left.\mathrm{ng} \mu \mathrm{L}^{-1}\right)$. All fractions were then concentrated to approximately $2 \mathrm{~mL}$ by rotary evaporation and dried with anhydrous 
granulated sodium sulfate. Acidic compounds present in the third fraction were methylated by the addition of a methanolic diazomethane solution. Afterwards, a surrogate standard $(200 \mu \mathrm{L})$ containing fluoroacetophenone (14.4 ng $\mu \mathrm{L}^{-1}$ ) was added to the third fraction. Prior to injection, all fractions were concentrated to final volumes of 10 to $50 \mu \mathrm{L}$ (first two fractions) and $200 \mu \mathrm{L}$ (third fractions).

\subsection{Gas Chromatography-Mass Spectrometry}

GC/MS analyses of the extracts were performed with a quadrupole ThermoQuest Trace MS mass spectrometer linked to a ThermoQuest Trace GC (ThermoQuest, Germany). The gas chromatograph was equipped with a ZB-5 fused silica capillary column (Phenomenex, Aschaffenburg, Germany; $30 \mathrm{~m} \times 0.25 \mathrm{~mm}$ ID $\times 0.25 \mu \mathrm{m}$ film thickness), and carrier gas velocity (helium) was ca. $40 \mathrm{~cm} \mathrm{~s}^{-1}$. A $1 \mu \mathrm{L} \mathrm{split/splitless} \mathrm{injection} \mathrm{(injector} \mathrm{temperature} \mathrm{of}$ $270^{\circ} \mathrm{C}$ ) was carried out at $60^{\circ} \mathrm{C}$ with a splitless time of $60 \mathrm{~s}$. After $3 \mathrm{~min}$ at the initial temperature, the oven was programmed to $310^{\circ} \mathrm{C}$ at a heating rate of $3^{\circ} \mathrm{C} \mathrm{min}^{-1}$ and $20 \mathrm{~min}$ isothermal time. Mass spectrometer operation took place in electron impact ionization mode $(\mathrm{EI}+, 70 \mathrm{eV})$ using a source temperature of $200^{\circ} \mathrm{C}$, scanning from 35 to $700 \mathrm{amu}$ at a rate of 2.5 scan s $^{-1}$ in low-resolution mode. Further details of chromatographic conditions and quantification procedures are given in Dsikowitzky et al. (2004b) and Grigoriadou et al. (2008).

\subsection{Compound Identification and Quantification}

Individual compounds were identified by comparison of EI+ mass spectra with those of mass spectral databases (NIST, Wiley) and published information. Furthermore, the identification was verified with mass spectra of purchased reference compounds to consider also specific gas chromatographic retention times and elution orders. Quantification was based on the integration of characteristic ion chromatograms extracted from the total ion current. In Supplementary information, all characteristic ions used for substance quantification are given. Response factors were obtained from four-point linear regression functions based on external calibration measurements with compound concentrations between $4 \mathrm{ng} \mu \mathrm{L}^{-1}$ and $40 \mathrm{ng} \mu \mathrm{L}^{-1}$ (injection of $1 \mu \mathrm{L}$ ). These concentrations ranged within the expected values of the compounds in the samples and within the linear detection range. If reference compounds were not commercially available, response factors of substances with a similar structure were used for quantification. The inaccuracies of injection and sample volume were corrected with the surrogate standard. The limit of detection (LOD) was in the range of $1 \mathrm{ng} \mathrm{L}^{-1}$, and the limit of quantification (LOQ) was in the range of $5 \mathrm{ng} \mathrm{L}^{-1}$.

\section{Results and Discussion}

3.1 Structural Diversity of Organic Contaminants in the Rur River

One main objective of this study was to determine the structural diversity of organic contaminants in the meso-scaled river system of the Rur river. Besides very well-known or widely distributed contaminants, also so far unknown or only sporadically identified substances have been detected.

In detail, the GC/MS-based non-target screenings over all sampling campaigns revealed the presence of more than 70 lipophilic to semi-polar substances. They were dominantly xenobiotic and therefore of anthropogenic origin. As summarized in Table 1, the substances can be divided into different categories based on their technical application or their chemical structures.

\subsubsection{Pharmaceuticals}

Pharmaceuticals as emerging contaminants have gained intensive scientific attention worldwide over the last two decades. They are widely used in both human and veterinary medicine and have been identified in various studies of different aqueous compartments as wastewater, surface water, groundwater, and recently also drinking water (e.g., Patel et al., 2019; Vulliet et al., 2011). However, since specific compounds target specific activities and, thus, have different effects on a target organism, this group is very heterogeneous. The substances show a high variety of chemical, physical, structural, and biological properties and, therefore, different environmental behaviors. Among others, caffeine, carbamazepine, diclofenac, and acetylsalicylic acid have been detected in the Rur river, which are known to be ubiquitous and 
Table 1 Concentration ranges $\left(\mathrm{ng} \mathrm{L}^{-1}\right)$ of organic compounds detected in Rur river water samples (taken in November 2020, March 2015, and November/December 2004)

\begin{tabular}{|c|c|c|c|c|}
\hline \multirow[t]{2}{*}{ No } & \multirow[t]{2}{*}{ Compounds } & \multicolumn{3}{|c|}{ Detected concentrations $\left(\mathrm{ng} \mathrm{L}^{-1}\right)$} \\
\hline & & November 2020 & March 2015 & $\begin{array}{l}\text { November } 2004 \text {, } \\
\text { December } 2004\end{array}$ \\
\hline \multicolumn{5}{|c|}{ Pharmaceuticals } \\
\hline 1 & Carbamazepine & n.d. -160 & n.d. -190 & n.d. -400 \\
\hline 2 & Oxcarbazepine & n.d. -30 & n.d & n.d \\
\hline 3 & Caffeine & n.d. -150 & $<5-70$ & n.d. -170 \\
\hline 4 & Chlorobutanol & n.d & n.d & n.d. -1600 \\
\hline 5 & Iminostilbene & n.d & n.d & n.d. -30 \\
\hline 6 & Lidocaine & n.d. -210 & n.d & n.d. -110 \\
\hline 7 & Acetylsalicylic acid & n.d & n.d & n.d. $-<5$ \\
\hline 8 & Diclofenac & n.d & n.a & n.d \\
\hline 9 & Tocopheryl acetate & n.d. -250 & n.d. -20 & n.d. -170 \\
\hline \multicolumn{5}{|c|}{ Personal care products } \\
\hline 10 & N,N,N',N'-Tetraacetylethylenediamine, TAED & n.d. -80 & n.d. -200 & n.d. -80 \\
\hline 11 & 4-Methoxycinnamic acid 2-ethylhexylester & n.d. $-<5$ & n.d. -10 & n.d. -220 \\
\hline 12 & Drometrizole & n.d. $-<5$ & n.d & n.d. -50 \\
\hline 13 & Galaxolide & n.d.-70 & $<5-100$ & $10-170$ \\
\hline 14 & Tonalide & n.d.-6 & $<5-9$ & $<5-30$ \\
\hline 15 & 4-Oxoisophorone & $<5-20$ & $<5-50$ & $20-120$ \\
\hline 16 & Lilial & n.d. $-<5$ & n.d. -30 & n.d. -10 \\
\hline 17 & Viridine & n.d & n.d & n.d. $-<5$ \\
\hline 18 & Dihydromethyljasmonate & $6-40$ & $<5-70$ & n.d. -20 \\
\hline 19 & Cineol & n.d & n.d. -40 & n.d. -160 \\
\hline 20 & Coumarin & n.d. -30 & n.d. -10 & n.d \\
\hline 21 & 4-tert-Butylcyclohexanone & n.d. -10 & n.d & n.d. -20 \\
\hline 22 & Benzophenone & $<5-30$ & n.d. -100 & $10-280$ \\
\hline 23 & Isopropyllaurate & $60-330$ & $1100-16,900$ & $20-500$ \\
\hline 24 & Isopropylpalmitate & $10-70$ & n.d. -3800 & $90-370$ \\
\hline 25 & Methyl dehydroabietate & $280-3800$ & $290-17,700$ & n.d. -280 \\
\hline \multicolumn{5}{|c|}{ Pesticides and biocides } \\
\hline 26 & N,N-Diethyltoluamide, DEET & n.d. -50 & n.d. -10 & n.d. -20 \\
\hline 27 & 4,4'-Dichlorobenzophenone, DBP & n.d & n.d & n.d. -240 \\
\hline \multicolumn{5}{|c|}{ Technical additives, plasticizers, and other industrial compounds } \\
\hline 28 & Di-iso-propylnaphthalenes, DIPN & n.d. $-<5$ & n.d. -110 & $10-30$ \\
\hline 29 & N-Butylbenzenesulfonamide, NBBS & n.d. -110 & n.d. -10 & n.d. -50 \\
\hline 30 & 2,4,4-Trimethylpentane-1,3-dioldi-iso-butyrate, TXIB & $10-70$ & n.d. -3700 & $5-30$ \\
\hline 31 & 2,4,7,9-Tetramethyl-5-decyne-4,7-diol, TMDD & $20-23,600$ & $100-24,600$ & $10-1700$ \\
\hline 32 & (1-Hydroxycyclohexyl)phenylketone, Irgacure 184 & n.d. -110 & $20-1500$ & n.d. $-<5$ \\
\hline 33 & Triethylcitrate & $<5-120$ & n.d. -540 & n.d. -40 \\
\hline 34 & Acetyl tributylcitrate & n.d. -340 & n.d. -540 & $<5-40$ \\
\hline 35 & Triacetin & $300-11,800$ & n.d. -1900 & n.d. -100 \\
\hline 36 & Triethylphosphate & n.d. -220 & n.d. -210 & n.d. -160 \\
\hline 37 & Tributylphosphate & n.d. -20 & n.d. -4300 & $10-730$ \\
\hline 38 & Tris(2-chloroethyl)phosphate, TCEP & n.d. -10 & n.d. -70 & n.d. -60 \\
\hline 39 & Tris(chloropropyl)phosphate, TCPP & $<5-110$ & n.d. -1200 & n.d. -40 \\
\hline
\end{tabular}


Table 1 (continued)

\begin{tabular}{|c|c|c|c|c|}
\hline \multirow[t]{2}{*}{ No } & \multirow[t]{2}{*}{ Compounds } & \multicolumn{3}{|c|}{ Detected concentrations $\left(\mathrm{ng} \mathrm{L}^{-1}\right)$} \\
\hline & & November 2020 & March 2015 & $\begin{array}{l}\text { November } 2004 \text {, } \\
\text { December } 2004\end{array}$ \\
\hline 40 & Triphenylphosphate & n.d & n.d. -160 & $<5-10$ \\
\hline 41 & Triphenylphosphine oxide & n.d. -260 & n.d. -60 & n.d \\
\hline 42 & Dimethyl phthalate & $10-70$ & $30-1000$ & n.d. -10 \\
\hline 43 & Diethyl phthalate & $50-220$ & $120-2500$ & $180-700$ \\
\hline 44 & Di-iso-butyl phthalate & $30-460$ & $170-3900$ & $<5-120$ \\
\hline 45 & Di-n-butyl phthalate & $70-1200$ & $210-2600$ & $130-620$ \\
\hline 46 & Benzyl butyl phthalate & n.d. -40 & n.d. -150 & n.d. -360 \\
\hline 47 & Bis(2-ethylhexyl) phthalate, DEHP & $230-1400$ & $180-4400$ & n.d. -760 \\
\hline 48 & 2,2-Dimethoxy-1,2-diphenylethanone, DMPA & n.d. -40 & n.d & n.d \\
\hline 49 & Diphenoxyethane & n.d. -10 & n.d. -90 & n.d. -40 \\
\hline \multicolumn{5}{|c|}{ Miscellaneous contaminants } \\
\hline \multicolumn{5}{|c|}{ Halogenated compounds } \\
\hline 50 & Dichloroaniline & n.d. -8 & n.d & n.d. -10 \\
\hline 51 & 1,1,2,2-Tetrachloroethane & n.d. -370 & n.d. -6 & n.d. -20 \\
\hline 52 & 4-Bromoanisole & n.d & n.d & $<5-180$ \\
\hline 53 & 2,4-Dibromoanisole & n.d & n.d & n.d. -20 \\
\hline 54 & 2,4,6-Tribromoanisole & n.d & n.d & $<5$ \\
\hline \multicolumn{5}{|c|}{ S-containing compounds } \\
\hline 55 & Diphenylsulfone & n.d. -20 & n.d. -80 & n.d \\
\hline 56 & Methylphenylsulfone & n.d. -40 & n.d & n.d. -20 \\
\hline 57 & Benzothiazole & n.d. -8 & n.d. -20 & $<5-20$ \\
\hline 58 & 2-Methylthiobenzothiazole & n.d. -70 & n.d. -50 & n.d. $-<5$ \\
\hline 59 & N-Phenylbenzenesulfonamide & n.d. -40 & n.d. -10 & n.d. -10 \\
\hline 60 & $\mathrm{~N}$-Ethyl-o-toluenesulfonamide & n.d. -180 & n.d. -20 & n.d. -30 \\
\hline 61 & N-Ethyl- $p$-toluenesulfonamide & n.d. -250 & n.d. -90 & n.d. -120 \\
\hline 62 & 2-Aminodiphenylsulfone & n.d & n.d & n.d. -10 \\
\hline \multicolumn{5}{|c|}{$\mathrm{N}$-containing compounds } \\
\hline 63 & 2-Methylbenzotriazole & n.d.-290 & n.d. -10 & n.d. -30 \\
\hline 64 & Quinoline & n.d. -20 & n.d.-9 & $<5-10$ \\
\hline 65 & Quinoxaline & n.d & n.d & n.d. $-<5$ \\
\hline 66 & 2,3-Diethyl-2,3-dimethylsuccinonitrile & n.d. $-<5$ & n.d. $-<5$ & n.d. -170 \\
\hline 67 & Phenylisocyanate & n.d. -140 & n.d & n.d \\
\hline 68 & Azobisisobutyronitrile, AIBN/Tetramethylsuccinonitrile, TMSN & n.d. -1300 & n.d. -120 & n.d. -70 \\
\hline 69 & N,N-Dibutylformamide & $120-560$ & $7-750$ & $20-160$ \\
\hline \multicolumn{5}{|c|}{ O-containing compounds } \\
\hline 70 & 2,6-Di-tert-butyl-1,4-benzoquinone, BHT-quinone & n.d. -40 & $10-100$ & n.d. -10 \\
\hline 71 & Butylated hydroxytoluene, Ionole & $5-20$ & n.d. -330 & $10-40$ \\
\hline 72 & 1,3,3-Trimethyloxindole & n.d. -30 & n.d.-10 & n.d \\
\hline
\end{tabular}

n.d. (not detected) means the concentration was below the detection limit $\left(<1 \mathrm{ng} \mathrm{L^{-1 }}\right) ;<5$ means the concentration was below the limit of quantification and above the detection limit $\left(1-5 \mathrm{ng} \mathrm{L}^{-1}\right)$; n.a. means not analyzed

frequently detected compounds (Hughes et al., 2013). Acetylsalicylic acid was only detected below the limit of quantification, but the detected concentrations of carbamazepine (up to $400 \mathrm{ng} \mathrm{L}^{-1}$ ) and caffeine (up 
to $170 \mathrm{ng} \mathrm{L}^{-1}$ ) were similar to other studies (Brezina et al., 2017; Hughes et al., 2013; Zhang et al., 2007).

However, also some uncommon and less frequently detected pharmaceuticals were identified. The amino compound lidocaine is a local anesthetic and antiarrhythmic agent that was firstly synthesized in the 1950s, and since then, it has been used extensively for medical applications. In high doses, it can have a neurotoxic effect (Holmdahl, 1998). However, even though lidocaine is widespread used, it has only sporadically been noted as an environmental contaminant. Rúa-Gómez and Püttmann have investigated its presence in German wastewater treatment plants and the corresponding impact on surface water quality (2012a, b). They have shown that lidocaine is constantly discharged by WWTP effluents as our conventional wastewater treatment does not remove it. At this point, Rúa-Gómez and Püttmann recognized a direct relationship between the amount of connected population and discharge levels. Its maximum concentration in the Rur river was $210 \mathrm{ng} \mathrm{L}^{-1}$, which is comparable to other German rivers (max. $176 \mathrm{ng} \mathrm{L}^{-1}$ ) that have been investigated by Rúa-Gómez and Püttmann (2012a). Besides lidocaine, also chlorobutanol (sedative hypnotic and local anesthetic), oxcarbazepine (anticonvulsant, derivate of carbamazepine), and iminostilbene (metabolite of carbamazepine) have been detected as noteworthy pharmaceuticals with maximum concentrations between $30 \mathrm{ng} \mathrm{L}^{-1}$ and $1.6 \mu \mathrm{g} \mathrm{L}^{-1}$.

\subsubsection{Personal Care Products}

Similar to pharmaceuticals, personal care products (PCPs) are also a very diverse group of compounds and are typically released via municipal wastewater effluents. Both substance classes are consumed by humans in rather large quantities. The group of PCPs typically includes constituents of lotions, detergents, deodorants, toothpaste, or cleaning products. Compounds that are frequently detected in various surface waters include, e.g., fragrances or synthetic musk compounds as galaxolide or tonalide (Dsikowitzky et al., 2002). They have been identified in the Rur river with concentrations up to $170 \mathrm{ng} \mathrm{L}^{-1}$ and $30 \mathrm{ng} \mathrm{L}^{-1}$, respectively. However, several further fragrances have also been identified in this catchment area in a wide range of concentrations between LOQ and $160 \mathrm{ng} \mathrm{L}^{-1}$ (lilial, cineol, dihydromethyljasmonate, viridine, coumarin). Most of them have only been rarely documented as water contaminants so far (Klaschka et al., 2013; Matamoros et al., 2012). Some can be of both natural and artificial origin; hence, an exclusive anthropogenic emission cannot be assumed (e.g., coumarin). However, lilial (or butylphenyl methylpropional) is a synthetic aromatic aldehyde that has a floral scent and no known natural source (Bolek \& Kümmerer, 2010). It is considered a contact allergen and must therefore be labeled in cosmetic products according to the EU Directive 2003/15/EC (European Commission, 2003). Godayol et al. (2015) have shown that it cannot be efficiently removed in WWTPs by conventional activated sludge treatments, where they even refer to Lilial as the most persistent fragrance allergen. Since it can be easily oxidized, metabolization might be of relevance and requires further investigations (Klaschka et al., 2013).

The substance 4-oxoisophorone is also used in the perfume and fragrance industry. It has been detected ubiquitously in the Rur river with concentrations between LOQ and $120 \mathrm{ng} \mathrm{L}^{-1}$. Similar results in terms of occurrence and concentrations have been obtained in other studies, such as in the German rivers Lippe and Rhine (Dsikowitzky et al., 2004a, b; Schwarzbauer \& Heim, 2005). Nevertheless, it has not received much attention beyond that. Of emerging interest is also the fragrance compound 4-tert-butylcyclohexanone that was only detected with low concentrations up to $20 \mathrm{ng} \mathrm{L}^{-1}$. According to ECHA, it is toxic to aquatic life with long-lasting effects. However, to the author's knowledge, 4-tert-butylcyclohexanone has only been reported in individual studies, so that the fate and behavior in the environment remains mainly unknown (Johnstone et al., 2020; Jüttner, 1999).

Besides fragrances, PCPs also include other substances and substance groups present in the Rur river. For instance, UV filters (benzophenone, drometrizole, 4-methoxycinnamic acid 2-ethylhexylester) or tetraacetylethylenediamine (TAED), a bleaching activator in laundry detergents, have been detected in concentrations up to $280 \mathrm{ng} \mathrm{L}^{-1}$. TAED has been detected in surface water systems in only a few studies (Schwarzbauer \& Ricking, 2010), and due to its high biodegradability and good photolysis in the presence of $\mathrm{Fe}$ (III) only at low concentrations (Brand et al., 1997; Schwientek et al., 2016; Sýkora et al., 2001). 


\subsubsection{Pesticides and Biocides}

$\mathrm{N}, \mathrm{N}$-Diethyl-m-toluamide (DEET) is mainly used as an insect repellent and has been detected in the Rur river with a maximum of $50 \mathrm{ng} \mathrm{\textrm {L } ^ { - 1 }}$ comparable to several surface waters worldwide (Aronson et al., 2012). It is commonly found in the aquatic environment, but its probability for adverse risks is low (Aronson et al., 2012; Weeks et al., 2012). In this study, DEET occurs only downstream of the WWTP Düren, which shows that wastewater effluents, in general, are an important input pathway for this substance. Nowadays, DEET is standardly considered in several surveys and offers a high potential as a molecular marker (Dsikowitzky et al., 2014b; Weeks et al., 2012). Eventually, benzothiazole (BT) and 2-methylthiobenzothiazole (MTBT) can also be assigned to this group as they are known degradation products of the fungicide 2-(thiocyanomethylthio)benzothiazole (Reemtsma et al., 1995). However, substances based on benzothiazole have widespread applications in industrial processes, e.g., in the tire and rubber manufacturing industry (Fiehn et al., 1994; Kloepfer et al., 2004). Nevertheless, BT and MTBT are of concern because of their limited biodegradability and potential aquatic toxicity, and they have been identified as environmental pollutants in several studies (Asimakopoulos et al., 2013; Hidalgo-Serrano et al., 2019; Reemtsma et al., 1995). In this study, the maximum concentrations were rather low, with $20 \mathrm{ng} \mathrm{L}^{-1}$ (BT) and $70 \mathrm{ng} \mathrm{L}^{-1}$ (MTBT) (cf. Dsikowitzky et al., 2017).

\subsubsection{Technical Additives, Plasticizers, and Other Industrial Compounds}

This group includes many and very diverse substances with different molecular structures as well as chemical and physical properties. Compounds that have been detected in the Rur river include wellknown water contaminants such as organophosphate flame retardants respectively plasticizers (TCPP, TCEP, TBP, TEP, TPP) (e.g., Cristale et al., 2013; Kim \& Kannan, 2018; Regnery \& Püttmann, 2010). They have been found in a wide range of concentrations from LOQ up to $1.2 \mu \mathrm{g} \mathrm{L}^{-1}$, with high concentrations of TCPP comparable, e.g., to those found in Iberian rivers (Gorga et al., 2015). Due to their high production volumes and extensive usage, there is growing concern about their fate and behavior in the aquatic environment (Cristale et al., 2013; Pantelaki \& Voutsa, 2019). Earlier studies have determined that some of them can have toxic effects on living organisms (Cristale et al., 2013; Reemtsma et al., 2008; van der Veen \& Boer, 2012). Since they are typically highly water-soluble, drinking water contamination is also of significant and current interest (Kim \& Kannan, 2018; Reemtsma et al., 2008; van der Veen \& Boer, 2012).

However, one substance that has only been recognized as an indicative marker for industrial effluents in recent years is the synthetic intermediate triphenylphosphine oxide (TPPO) (Botalova et al., 2009). Since then, it has been recognized as an environmental contaminant in a few studies (Bollmann et al., 2012; Wang et al., 2015). Nevertheless, according to Wang et al. (2015), TPPO is harmful to aquatic organisms and may cause long-term adverse effects in the aquatic environment. Thus, special attention should be given to corresponding contaminations. In the Rur river, this phosphorous-containing compound has been detected at all sampling locations downstream of the WWTP Düren with up to $260 \mathrm{ng} \mathrm{L}^{-1}$. Furthermore, several other plasticizers (e.g., phthalate-based plasticizers, NBBS, TXIB) and citrate esters have been detected with maximum concentrations between $110 \mathrm{ng} \mathrm{L}{ }^{-1}$ (NBBS) and $12 \mu \mathrm{g} \mathrm{L}^{-1}$ (triacetin). For instance, due to its properties (lack of odor, low toxicity), acetyl tributylcitrate (ATBC) is commonly used as a phthalate substitute in pharmaceutical drugs or cosmetics (Takeshita et al., 2011). Nevertheless, Takeshita et al. (2011) suggest handling ATBC products with care as they may lead to altered metabolism of endogenous steroid hormones and prescription drugs.

Especially the paper industry is quite specific for the emission situation of the Rur so that the identification of corresponding industrial substances as triacetin, 2,4,7,9-tetramethyl-5-decyne-4,7-diol (TMDD), DIPN, or Irgacure 184 with partly high concentrations up to $25 \mu \mathrm{g} \mathrm{L}^{-1}$ is not surprising. However, the surfactant TMDD and the photoinitiator Irgacure 184 have been detected in several different river systems, so that these substances are recommended for international high-scale monitoring programs rather than for regional approaches intended to cover the real state of pollution (Schwarzbauer \& Ricking, 2010). Botalova et al. (2011) suggested triacetin as a potential marker for paper production and printing inks because it has 
been detected in the effluent of an industrial plant specialized in the manufacture of paper, special cosmetic and pharmaceutical products, as well as materials for printing inks. Furthermore, according to Dsikowitzky et al. (2015), 2,2-dimethoxy-2-phenylacetophenone (DMPA) and diphenoxyethane are characteristic compounds of wastewaters from modern paper production sites. However, they are only reported in German wastewater influents but were not detected in the receiving water. Nevertheless, in the Rur catchment, both substances were found with concentrations up to $40 \mathrm{ng} \mathrm{L}^{-1}$ (DMPA) and $90 \mathrm{ng} \mathrm{L}^{-1}$ (diphenoxyethane) downstream of the WWTP Düren, questioning the input of insufficiently treated wastewaters of the paper industry. Generally, data on behavior and fate is still missing as these compounds have only scarcely been identified in the aquatic environment.

\subsubsection{Miscellaneous Contaminants}

In addition, further halogenated and sulfur-, nitrogen-, or oxygen-containing compounds have been detected in the Rur river with maximum concentrations between LOQ and $1300 \mathrm{ng} \mathrm{L}^{-1}$ that were not able to be assigned to specific emission sources. Some of them have already been described as emerging or even common contaminants of the aquatic environment (e.g., 2-methyl-2H-benzotriazole or quinoline). The $\mathrm{N}$-heterocyclic quinoline is used in several industrial processes but also occurs naturally in the environment (Felczak et al., 2016). It is widely distributed and frequently detected in water and soil, but nevertheless, it shows a high ecotoxic potential (Felczak et al., 2016; Neuwoehner et al., 2009). However, the maximum concentration of quinoline in the Rur river was only $20 \mathrm{ng} \mathrm{L}^{-1}$.

2,6-Di-tert-butyl-p-benzoquinone (BHT-quinone) is an oxidant and polymerization catalyst and also known as a transformation product of 2,6-ditert-butyl-4-methylphenol/butylated hydroxytoluene (BHT) (Liu \& Mabury, 2020; Ma et al., 2006). These substances have been detected with maximum concentrations of $330 \mathrm{ng} \mathrm{L}^{-1}$ (BHT) and $100 \mathrm{ng} \mathrm{L}^{-1}$ (BHT-quinone) (cf. Moldovan et al., 2018). BHT is a synthetic phenolic antioxidant that is extensively used and has gained much attention. Recently, however, there has been growing concern about toxic effects, environmental pollution, and challenges for water reuse due to its metabolite BHT-quinone (Liu
\& Mabury, 2020; Wu et al., 2019). Earlier studies have shown that it can cause DNA damage even at low concentrations (Nagai et al., 1993). However, further knowledge about sources, fates, and behavior is still lacking.

Finally, a nitrogen-containing substance was detected in the Rur river with a maximum concentration of around $1.3 \mu \mathrm{g} \mathrm{L}^{-1}$. It has been identified as azobisisobutyronitrile (AIBN) or its degradation product tetramethylsuccinonitrile (TMSN). AIBN is a well-known and widely used radical initiator for various polymer and organic syntheses (Malow et al., 2015; Yamashina et al., 2014). By releasing elemental nitrogen $\mathrm{N}_{2}$, AIBN generates organic radical species (Yamashina et al., 2014). Since this can be a thermally introduced process, the mass spectra of AIBN and TMSN obtained by GC/MS cannot be differentiated, as the hot gas chromatographic injection may produce the derivative from the original compound. However, these substances have different effects on the environment as TMSN shows acute toxic properties (Johannsen \& Levinskas, 1986). Nevertheless, to the authors' knowledge, up to now, both have not been identified as environmental contaminants. Thus, there is no information available regarding their behaviors and fates, and further research is required.

\subsection{Emission Profiles and Spatial Distribution of Selected Contaminants}

Another major objective of this study was to determine emission characteristics and patterns of the diverse contaminants to determine their specific environmental behaviors. Therefore, emission profiles showing the load over the entire longitudinal section of the river were calculated and categorized. In this context, loads are clearly more informative than concentrations as changing river runoffs affect the compound concentrations, but not the loads. Thus, spatial distributions along the river course can be assessed in detail. In principle, increasing loads indicate the input of a substance, e.g., by wastewater effluents, whereas decreasing loads show a removal from the water phase. Possible processes here are partitioning into other phases (e.g., as volatilization or adsorption to particulate matter) or degradation of the substance in the aquatic environment. Depending on the physicochemical properties of the compounds, this results in 
emission profiles that allow an estimation and assessment of the environmental behavior and fate.

According to the input of the individual substances, a general distinction was made between profiles showing local point and multiple to diffuse sources. As the data from 2020 shows the current exposure situation and variety of organic contaminants, the profiles are based on this campaign, while the next section provides a more detailed look at temporal variations. According to Dsikowitzky et al. (2015), the load $\left(\mathrm{g} \mathrm{d}^{-1}\right)$ was calculated with the compound concentration in water, $\mathrm{C}\left(\mathrm{ng} \mathrm{L}^{-1}\right)$, and the median river runoff, $\mathrm{MQ}\left(\mathrm{m}^{3} \mathrm{~s}^{-1}\right)$, as follows:

$L=C x M Q x\left(3600 \times 24 / 10^{6}\right)$.

Further river data used for calculation are given in Supplementary information. An overview of the detected concentrations and loads can be found in Table 1 and Table 2, respectively.

\subsubsection{Emission Profiles Showing One Local Main Emitter}

In general, cities and their corresponding WWTPs are often local hotspots resulting in higher concentrations and increasing loads at the specific location. Located directly on the Rur river, Düren $(91,000$ inhabitants in 2020) is the biggest and most important agglomeration. However, regarding the entire catchment, Aachen (249,000 inhabitants in 2020) represents the biggest city, located at the Wurm tributary which flows into the Rur river north of Heinsberg, close to the Dutch-German border. Thus, these cities hold also the largest WWTPs in this area with treated annual wastewater volumes of 28 million $\mathrm{m}^{3}$ (Aachen) and 21 million $\mathrm{m}^{3}$ (Düren) (Wasserverband Eifel-Rur, 2017b). Especially, the WWTP Düren has an enormous influence on the river contamination as it discharges its effluents directly into the Rur itself. Many substances have only been identified at the corresponding sampling location (R11) and downstream. Nevertheless, they show differences in their environmental behavior and stability. For some, the loads decrease rapidly after this point source, while for others, they remain constant or even increase.

\section{Significant Increase due to WWTPs and Subse- quently Decreasing Loads The sulfur-containing}

compound methylphenylsulfone shows a clear increase in both concentrations and loads at the sampling location downstream of the WWTP Düren (R11). At this location, loads of $25 \mathrm{~g} \mathrm{~d}^{-1}$ were determined while it was not detected earlier (cf. Figure 2). Furthermore, directly at the next location R12 (9.5 km downstream of WWTP), the values were close to the quantification limit again. Another increase at sampling location R14 can be traced back to the input of the WWTP Jülich (treated annual wastewater volume of 5 million $\mathrm{m}^{3}$ in 2016). In this case, too, concentrations and loads quickly decrease again. This indicates a dynamic environmental behavior, characterized by local emissions and rapid elimination as the result of, e.g., low stability, partitioning into other phases or rapid degradation. However, methylphenylsulfone is only rarely documented as a riverine contaminant, and corresponding studies are lacking. While Schwarzbauer and Heim (2005) also mentioned, among others, the emission pathway as a metabolite of the herbicide planavin, the present emission profile implies either industrial or municipal sources. Similar emission profiles occurred for phenyl isocyanate, oxcarbazepine, or TPPO. For all of them, the WWTP Düren is the local main emitter. The inflow of smaller WWTPs or the Wurm and, thus, the effluents of the WWTP Aachen did not lead to any significant increases in loads. This could be attributed to the low environmental stability of the specific compounds that got obvious within the emission profiles. In particular, after the long flow path from the discharge of the WWTP Aachen into the Wurm to the confluence with the Rur (around $45 \mathrm{~km}$ ), no additional high loads are thus to be expected.

\section{Significant Increase due to WWTPs and Subse-} quently Constant Loads This type of substance also shows a local main emitter (generally the WWTP Düren) and subsequently almost constant loads. Similar to methylphenylsulfone, the emission profile of $\mathrm{N}$-phenylbenzenesulfonamide clearly shows inputs from wastewater treatment plants. As shown in Fig. 2, the loads remain about the same, which indicates higher stability and the relative persistence of this substance in the water phase. However, this substance is also practically unknown as an environmental contaminant.

Better-known examples of this emission type are organophosphate flame retardants. Detected 
Table 2 Span of minimum and maximum loads $\left(\mathrm{g} \mathrm{d}^{-1}\right)$ of organic compounds detected in Rur river water samples (taken in November 2020, March 2015, and November/December 2004)

\begin{tabular}{|c|c|c|c|c|}
\hline \multirow[t]{2}{*}{ No } & \multirow[t]{2}{*}{ Compounds } & \multicolumn{3}{|c|}{ Detected loads $\left(\mathrm{g} \mathrm{d}^{-1}\right)$} \\
\hline & & November 2020 & March 2015 & $\begin{array}{l}\text { November } 2004 \\
\text { December } 2004\end{array}$ \\
\hline \multicolumn{5}{|c|}{ Pharmaceuticals } \\
\hline 1 & Carbamazepine & $0-124$ & $0-225$ & 0-935 \\
\hline 2 & Oxcarbazepine & $0-17$ & 0 & 0 \\
\hline 3 & Caffeine & $0-110$ & $1-87$ & $0-410$ \\
\hline 4 & Chlorobutanol & 0 & 0 & $0-3235$ \\
\hline 5 & Iminostilbene & 0 & 0 & $0-71$ \\
\hline 6 & Lidocaine & $0-125$ & 0 & $0-259$ \\
\hline 7 & Acetylsalicylic acid & 0 & 0 & $0-<24$ \\
\hline 8 & Diclofenac & 0 & 0 & 0 \\
\hline 9 & Tocopheryl acetate & $0-48$ & $0-11$ & $0-348$ \\
\hline \multicolumn{5}{|c|}{ Personal care products } \\
\hline 10 & N,N,N',N'-Tetraacetylethylenediamine, TAED & $0-59$ & $0-247$ & $0-164$ \\
\hline 11 & 4-Methoxycinnamic acid 2-ethylhexylester & $0-<8$ & $0-20$ & $11-450$ \\
\hline 12 & Drometrizole & $0-1$ & 0 & $0-126$ \\
\hline 13 & Galaxolide & $0-56$ & $<1-113$ & $3-401$ \\
\hline 14 & Tonalide & $0-5$ & $<1-12$ & $<1-71$ \\
\hline 15 & 4-Oxoisophorone & $1-12$ & $1-63$ & $6-204$ \\
\hline 16 & Lilial & $0-<8$ & $0-41$ & $0-24$ \\
\hline 17 & Viridine & 0 & 0 & $0-<24$ \\
\hline 18 & Dihydromethyljasmonate & $3-29$ & $3-92$ & $0-55$ \\
\hline 19 & Cineol & 0 & $0-55$ & $0-377$ \\
\hline 20 & Coumarin & $0-19$ & $0-14$ & 0 \\
\hline 21 & 4-tert-Butylcyclohexanone & $0-9$ & 0 & $0-41$ \\
\hline 22 & Benzophenone & $<1-18$ & $0-113$ & $2-305$ \\
\hline 23 & Isopropyllaurate & $22-271$ & $116-24,231$ & $3-593$ \\
\hline 24 & Isopropylpalmitate & $3-48$ & $7-2372$ & $9-745$ \\
\hline 25 & Methyl dehydroabietate & $122-3078$ & $76-25,386$ & $0-36$ \\
\hline \multicolumn{5}{|c|}{ Pesticides and biocides } \\
\hline 26 & N,N-Diethyltoluamide, DEET & $0-27$ & $0-12$ & $0-47$ \\
\hline 27 & 4,4'-Dichlorobenzophenone, DBP & 0 & 0 & $0-477$ \\
\hline \multicolumn{5}{|c|}{ Technical additives, plasticizers, and other industrial compounds } \\
\hline 28 & Di-iso-propylnaphthalenes, DIPN & $0-<8$ & $0-105$ & $1-54$ \\
\hline 29 & N-Butylbenzenesulfonamide, NBBS & $0-67$ & $0-13$ & $0-118$ \\
\hline 30 & 2,4,4-Trimethylpentane-1,3-dioldi-iso-butyrate, TXIB & $3-42$ & $25-419$ & $2-66$ \\
\hline 31 & 2,4,7,9-Tetramethyl-5-decyne-4,7-diol, TMDD & $4-14,294$ & $32-83,863$ & $1-4027$ \\
\hline 32 & (1-Hydroxycyclohexyl)phenylketone, Irgacure 184 & $0-16$ & $8-1967$ & $0-<24$ \\
\hline 33 & Triethylcitrate & $1-70$ & $0-351$ & $0-94$ \\
\hline 34 & Acetyl tributylcitrate & $0-48$ & $0-774$ & $<1-82$ \\
\hline 35 & Triacetin & $234-6579$ & $39-2474$ & 0-197 \\
\hline 36 & Triethylphosphate & $0-158$ & $0-281$ & $0-366$ \\
\hline 37 & Tributylphosphate & $0-13$ & $0-5638$ & $2-1717$ \\
\hline 38 & Tris(2-chloroethyl)phosphate, TCEP & $0-8$ & $0-43$ & $0-130$ \\
\hline 39 & Tris(chloropropyl)phosphate, TCPP & $<1-68$ & $0-769$ & $0-74$ \\
\hline
\end{tabular}


Table 2 (continued)

\begin{tabular}{|c|c|c|c|c|}
\hline \multirow[t]{2}{*}{ No } & \multirow[t]{2}{*}{ Compounds } & \multicolumn{3}{|c|}{ Detected loads $\left(\mathrm{g} \mathrm{d}^{-1}\right)$} \\
\hline & & November 2020 & March 2015 & $\begin{array}{l}\text { November } 2004 \\
\text { December } 2004\end{array}$ \\
\hline 40 & Triphenylphosphate & 0 & $0-105$ & $<1-12$ \\
\hline 41 & Triphenylphosphine oxide & $0-206$ & $0-73$ & 0 \\
\hline 42 & Dimethyl phthalate & $2-52$ & $5-995$ & $0-24$ \\
\hline 43 & Diethyl phthalate & $12-117$ & $0-3233$ & $45-1644$ \\
\hline 44 & Di-iso-butyl phthalate & $19-370$ & $51-3375$ & $8-165$ \\
\hline 45 & Di- $n$-butyl phthalate & $33-970$ & $47-1562$ & $29-850$ \\
\hline 46 & Benzyl butyl phthalate & $0-12$ & $0-143$ & $7-386$ \\
\hline 47 & Bis(2-ethylhexyl) phthalate, DEHP & $105-1060$ & $56-6245$ & $0-827$ \\
\hline 48 & 2,2-Dimethoxy-1,2-diphenylethanone, DMPA & $0-24$ & 0 & 0 \\
\hline 49 & Diphenoxyethane & $0-6$ & $0-18$ & $0-104$ \\
\hline \multicolumn{5}{|c|}{ Miscellaneous contaminants } \\
\hline \multicolumn{5}{|c|}{ Halogenated compounds } \\
\hline 50 & Dichloroaniline & $0-<8$ & 0 & $0-24$ \\
\hline 51 & 1,1,2,2-Tetrachloroethane & $0-253$ & $0-<14$ & $0-45$ \\
\hline 52 & 4-Bromoanisole & 0 & 0 & $1-197$ \\
\hline 53 & 2,4-Dibromoanisole & 0 & 0 & $0-<24$ \\
\hline 54 & 2,4,6-Tribromoanisole & 0 & 0 & $<1-<24$ \\
\hline \multicolumn{5}{|c|}{ S-containing compounds } \\
\hline 55 & Diphenylsulfone & $0-14$ & $0-104$ & 0 \\
\hline 56 & Methylphenylsulfone & $0-25$ & 0 & $0-45$ \\
\hline 57 & Benzothiazole & $0-6$ & $0-18$ & $<1-47$ \\
\hline 58 & 2-Methylthiobenzothiazole & $0-42$ & $0-63$ & $0-<24$ \\
\hline 59 & N-Phenylbenzenesulfonamide & $0-25$ & $0-<14$ & $0-24$ \\
\hline 60 & $\mathrm{~N}$-Ethyl-o-toluenesulfonamide & $0-111$ & $0-<14$ & $0-80$ \\
\hline 61 & N-Ethyl-p-toluenesulfonamide & $0-149$ & 0-93 & $0-288$ \\
\hline 62 & 2-Aminodiphenylsulfone & 0 & 0 & $0-<24$ \\
\hline \multicolumn{5}{|c|}{ N-containing compounds } \\
\hline 63 & 2-Methylbenzotriazole & $0-217$ & $0-18$ & $0-71$ \\
\hline 64 & Quinoline & $0-15$ & $0-15$ & $<1-24$ \\
\hline 65 & Quinoxaline & 0 & 0 & $0-<20$ \\
\hline 66 & 2,3-Diethyl-2,3-dimethylsuccinonitrile & $0-<8$ & $0-<14$ & 0-389 \\
\hline 67 & Phenylisocyanate & $0-129$ & 0 & 0 \\
\hline 68 & Azobisisobutyronitrile, AIBN/Tetramethylsuccinonitrile, TMSN & $0-756$ & $0-155$ & $0-172$ \\
\hline 69 & $\mathrm{~N}, \mathrm{~N}$-Dibutylformamide & $26-432$ & 3-989 & $7-363$ \\
\hline \multicolumn{5}{|c|}{ O-containing compounds } \\
\hline 70 & 2,6-Di-tert-butyl-1,4-benzoquinone, BHT-quinone & $0-10$ & $1-118$ & $0-31$ \\
\hline 71 & Butylated hydroxytoluene, Ionole & $1-13$ & $0-435$ & $2-75$ \\
\hline 72 & 1,3,3-Trimethyloxindole & $0-16$ & $0-16$ & 0 \\
\hline
\end{tabular}

compounds included TCEP, TCPP, and TEP, which all show similar profiles having the WWTP Düren as the most important emission source. These three substances all exhibit a high water solubility (TCEP:
$7 \mathrm{~g} \mathrm{~L}^{-1}$, TCPP: $1.2 \mathrm{~g} \mathrm{~L}^{-1}$, TEP: $50 \mathrm{~g} \mathrm{~L}^{-1}$ ) and a rather low $\log \mathrm{K}_{\mathrm{OW}}$ (TCEP: 1.63, TCPP: 2.89, TEP: 0.39). Thus, they are commonly detected in the aqueous phase (Kim \& Kannan, 2018; Pantelaki \& Voutsa, 

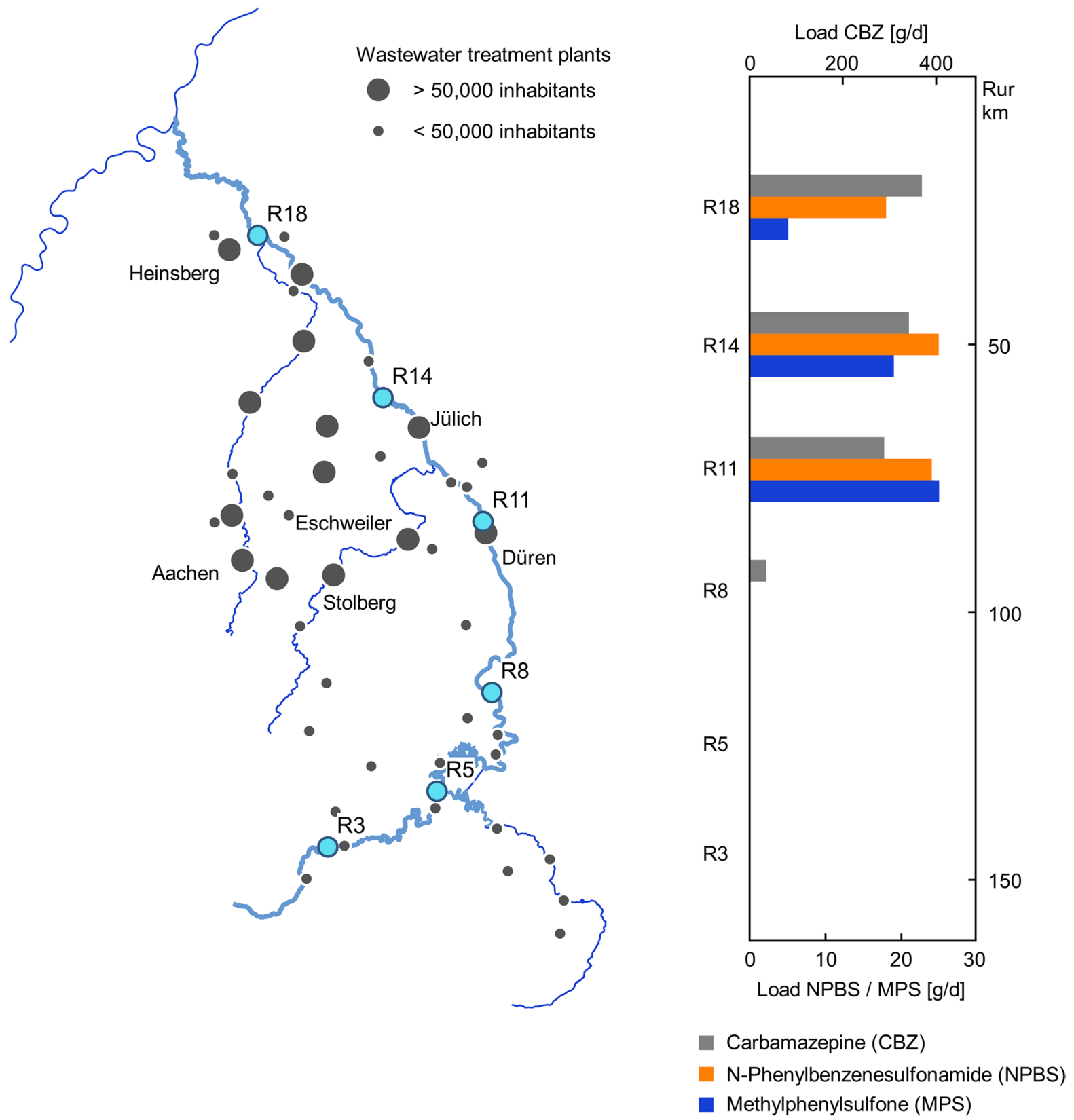

Fig. 2 Wastewater treatment plants in the Rur catchment and spatial distribution of carbamazepine, N-phenylbenzenesulfonamide, and methylphenylsulfone loads $\left(\mathrm{g} \mathrm{d}^{-1}\right)$ at six monitoring stations on the Rur. Sampling took place in November 2020

2019). Furthermore, TCEP and TCPP show a high persistence and do not degrade during wastewater treatment (Kim et al., 2017; Reemtsma et al., 2006). This clarifies both their introduction and the associated emission profiles. Similar conclusions also apply to TMDD (water solubility $1.7 \mathrm{~g} \mathrm{~L}^{-1}, \log \mathrm{K}_{\mathrm{OW}}$ 2.8), which, however, was detected with significantly higher concentrations and loads (up to $24 \mu \mathrm{g} \mathrm{L}^{-1}$ and $14 \mathrm{~kg} \mathrm{~d}^{-1}$ in 2020). Such high concentrations have already been attributed to its use in the paper industry which also occurs along the Rur river (Dsikowitzky et al., 2015; Guedez \& Püttmann, 2011). Guedez and Püttmann (2011) have also shown that its removal efficiency during wastewater treatment varies from 33 
to $68 \%$ and that its biodegradability was only $25.4 \%$ during 57 days using the OECD Tests Guide-line 302 A. These properties, therefore, also indicate certain stability and transport in river water.

\subsubsection{Emission Profiles Showing Multiple Anthropogenic Emitters}

Emission Profile with Increasing Loads This type includes emission profiles of substances that show various emission sources with strong variations of concentrations but increasing loads with the course of the river. In particular, many of the detected fragrances show a corresponding environmental behavior (galaxolide, dihydromethyljasmonate, 4-oxoisophorone, 4-tert-butylcyclohexanone, coumarin). The main emitter here is again the WWTP in Düren, but there are also other emission sources. In the case of dihydromethyljasmonate, the highest concentrations (up to $40 \mathrm{ng} \mathrm{L}^{-1}$ at R1) were detected in the upper reaches of the river. In this area, there are smaller WWTPs discharging directly into the Rur and tributary streams. However, the associated loads are very low due to the low river runoff in this area $\left(6 \mathrm{~g} \mathrm{~d}^{-1}\right.$ at R1). Schwarzbauer and Ricking (2010) identified dihydromethyljasmonate in several German and European rivers with the same multiplicity as the common synthetic musk compound galaxolide. According to its widespread distribution and the emission profile in the Rur river itself, dihydromethyljasmonate shows elevated stability and low degradation potential in the aqueous environment. Nowadays, it is therefore confirmed as a present environmental contaminant (Dey et al., 2019).

As visible in Fig. 2, increasing loads were also detected for the antiepileptic drug carbamazepine. The two largest emission sources can be assigned to the WWTPs Düren and Aachen. Here, the influence of the large volume of wastewater from Aachen can be seen despite its longer flow distance to the sampling point (Wurm tributary). This leads to conclusions about the stability of carbamazepine in the water phase. It exhibits a low removal efficiency at WWTPs as well as a low degradation potential and high persistence in the environment so that it has been detected in numerous studies worldwide (Clara et al., 2004; Durán-Álvarez et al., 2015; Leclercq et al., 2009). Interestingly, the structurally similar oxcarbazepine shows steadily decreasing loads after its first introduction at the WWTP Düren, indicating lower stability, degradation, or partitioning into other compartments. According to Leclercq et al. (2009), oxcarbazepine shows higher removal efficiencies in WWTPs than carbamazepine, and according to Kaiser et al. (2014), it is biodegradable. Furthermore, the toxicological evaluation suggested a reduced (geno-)toxicity compared to carbamazepine (Brezina et al., 2017). Thus, the environmental behavior of these structurally similar substances can be well differentiated.

Emission Profile with Varying Loads In contrast to the previously mentioned substances, there is no clear increase in loads of the plasticizer 2,2,4-trimethyl-1,3-pentanediol diisobutyrate (TXIB) along the river course. Nevertheless, it shows multiple emission sources. TXIB was also identified in a high multiplicity in the European rivers investigated by Schwarzbauer and Ricking (2010). The emission profile of the Rur river shows a ubiquitous presence with varying loads, but peaks that can clearly be assigned to wastewater treatment plants of different dimensions (cf. Figure 3). While the large plants in Düren and Jülich also treat industrial wastewater, the smaller ones treat mainly municipal wastewater revealing a municipal origin of TXIB. Also, according to Dsikowitzky et al. (2014a), it is a typical constituent of municipal sewage and is not readily biodegradable. However, overall, it can be assigned to a non-specific and diffuse origin as it was present at every sampling location. Very similar profiles with varying loads, but assignable main emission sources, were also observed for isopropyl laurate and N,N-dibutylformamide.

\subsubsection{Emission Profiles Showing no Specific Emitters}

Many substances of this profile type show a ubiquitous appearance. In contrast to the previously described profiles of, e.g., TXIB, no clear emission sources can be assigned. Examples of substances showing these emission profiles are various phthalates. These were detected at all sampling locations in varying concentrations and loads without any clear trend being identifiable. Comparable dynamic profiles were also found in earlier investigations from the Rhine river (Schwarzbauer \& Heim, 2005). As phthalates are well-known 
Fig. 3 Spatial distribution of TXIB loads $\left(\mathrm{g} \mathrm{d}^{-1}\right)$ over the entire river course with peak values at various wastewater treatment plant discharges (Düren, Jülich, Aachen) and tributaries (Kall, Wurm). Sampling took place in November 2020. The sampling sites are indicated in Fig. 1

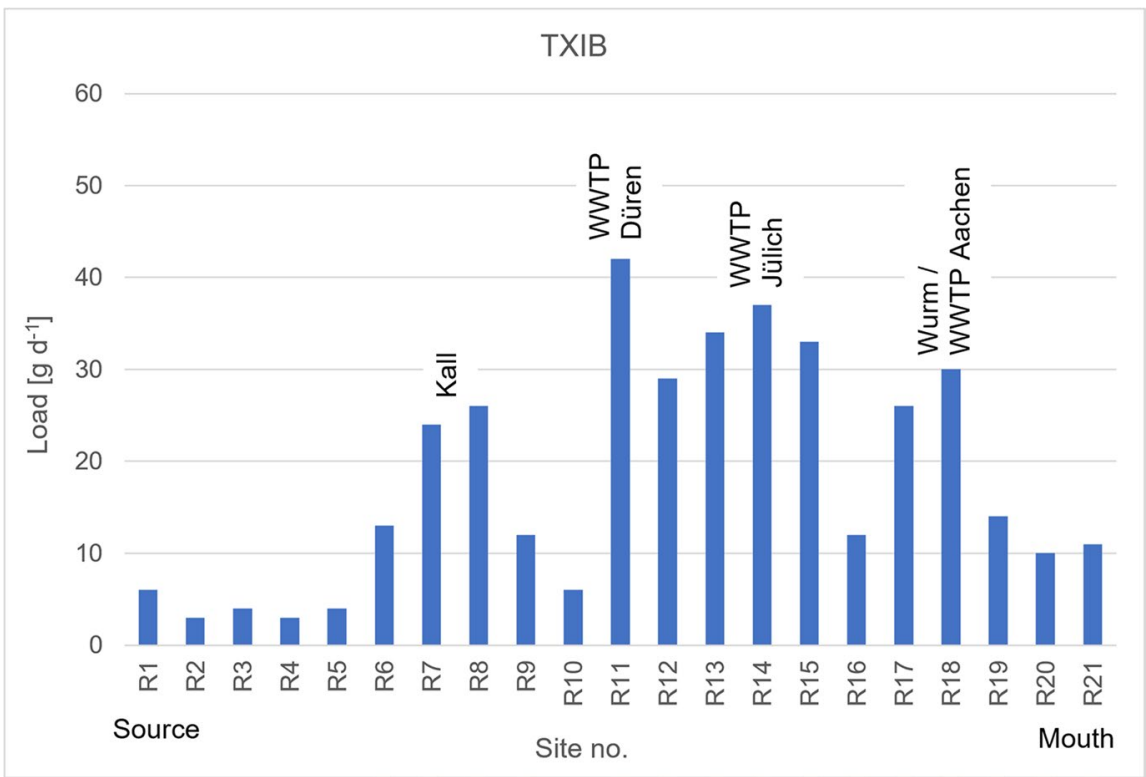

environmental contaminants, there are several studies on their introduction, fate, and toxicity (Fromme et al., 2002; Staples et al., 1997). Due to their high production volume and wide distribution, they are nowadays ubiquitous and among the most common compounds that humans come in contact with (Net et al., 2015). Even if their exposure does not lead to bioaccumulation, some phthalates are of concern due to their developmental and/or reproductive toxicity (Heudorf et al., 2007).

The emission profile of the plasticizer triacetin also shows no clearly recognizable trend. Very high concentrations were detected in both the upper and middle course $\left(12 \mu \mathrm{g} \mathrm{L}^{-1}\right.$ and $8.1 \mu \mathrm{g} \mathrm{L}^{-1}$, respectively), with the associated loads only showing a peak in the middle course. This peak is located near to the cities of Düren and Jülich and could possibly be attributed to the paper industry located there. However, due to the ubiquitous occurrence in this river system, the substance is not suitable as a marker for the paper industry at the Rur river.

Quinoline also shows a highly interesting emission profile having no clear emission sources. Its concentrations and loads are continuously increasing along the river's longitudinal section. This suggests a biogenic input.

\subsection{Temporal variations}

Another objective of this study was to investigate temporal variations in organic contamination and to determine whether it has decreased in recent decades. The general conditions regarding population development, water demand and effluent production have remained almost the same over the period under consideration. Nevertheless, since the water compartment, in particular, is highly dynamic, these samplings are only to be understood as snapshots of contamination. Nevertheless, general trends can be derived if, for example, a substance shows similar emission profiles over several campaigns. This is the only way to make reliable statements about environmental behavior and fate. Overall, 64 contaminants were identified in 2004, 54 contaminants in 2015, and 59 contaminants in 2020 . Thus, the detected contaminants show a high structural diversity in all sampling years. Due to new developments, but also new findings regarding the resistance and toxicity of the contaminants, the overall pollution load of the river changes, but nevertheless, the high diversity remains.

Especially, brominated and some chlorinated compounds (e.g., bromoanisole or chlorobutanol) were not detected in recent campaigns of 2015 and 2020. Due to their partly high environmental relevance, this can possibly be attributed to restrictions on use 
or even bans (Huang et al., 2014; Reemtsma et al., 2008). Furthermore, for a large number of substances, significantly lower loads were determined in 2020 than in the previous samplings. These include, for example, the substances galaxolide, tonalide, lilial, 4-methoxycinnamic acid 2-ethylhexylester, 2,3-diethyl-2,3-dimethylsuccinonitrile, and DIPN. While in 2004, galaxolide loads of up to $401 \mathrm{~g} \mathrm{~d}^{-1}$ were found; the maximum load in 2015 was $113 \mathrm{~g} \mathrm{~d}^{-1}$, and in 2020 it was even only $56 \mathrm{~g} \mathrm{~d}^{-1}$. Nevertheless, due to its persistence, the emission profiles are very similar with relatively constantly increasing loads (cf. Figure 4). This indicates a lower input into the water body, either due to a reduced use or higher removal efficiencies of the respective WWTPs. The other before-mentioned substances were no longer

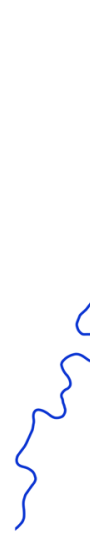

$$
\begin{aligned}
& \text { Wastewater treatment plants } \\
& >50,000 \text { inhabitants } \\
& <50,000 \text { inhabitants }
\end{aligned}
$$
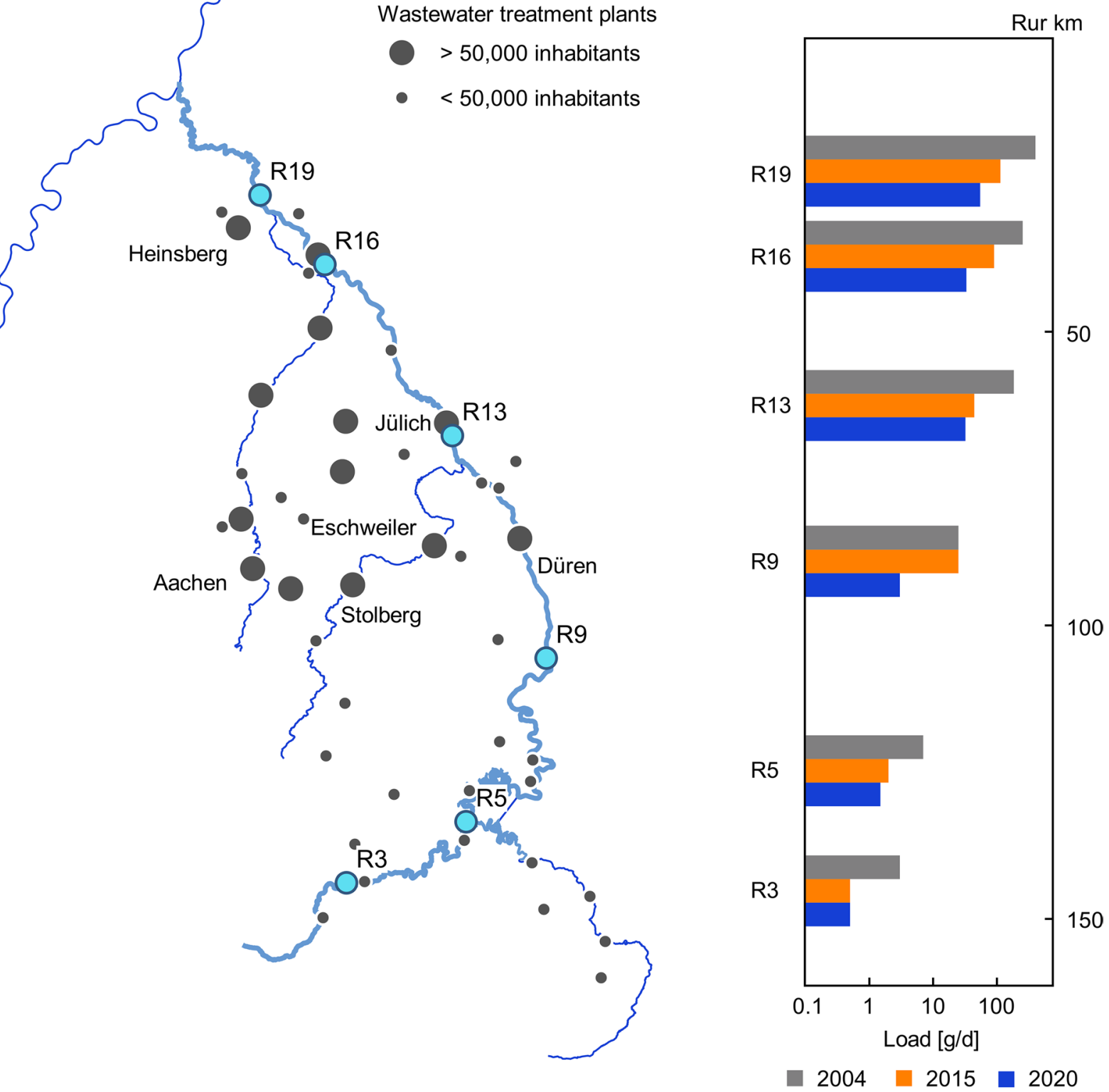

Fig. 4 Wastewater treatment plants in the Rur catchment and temporal as well as the spatial distribution of galaxolide loads $\left(\mathrm{g} \mathrm{d}^{-1}\right)$ at six monitoring stations on the Rur over three different sampling campaigns (please note the logarithmic illustration of the $x$-axis) 
detected beyond doubt in 2020. While in 2015, they were detected only sporadically and mostly with concentrations below the limit of quantification (except for DIPN); in 2004, they appeared in part with significantly higher concentrations and loads (4-methoxycinnamic acid 2-ethylheylester: $450 \mathrm{~g} \mathrm{~d}^{-1}$; 2,3-diethyl-2,3-dimethylsuccinonitrile: $389 \mathrm{~g} \mathrm{~d}^{-1}$; tonalide: $71 \mathrm{~g} \mathrm{~d}^{-1}$ ). DIPN was detected frequently in both 2004 and 2015 (maximum loads of $54 \mathrm{~g} \mathrm{~d}^{-1}$ and $99 \mathrm{~g} \mathrm{~d}^{-1}$ ), but only sporadically and below the limit of quantification in 2020.

In addition to substances with lower loads, nearly constant (e.g., for carbamazepine, caffeine, and triethyl citrate) or even higher loads also occurred for some substances (e.g., for TMDD, triacetin, and AIBN/TMSN). For TMDD, the values were significantly higher both in 2015 and 2020. In 2015, the maximum load was reached after the discharge of the WWTP Jülich $\left(84 \mathrm{~kg} \mathrm{~d}^{-1}\right)$ and in 2020 after the WWTP Düren $\left(14 \mathrm{~kg} \mathrm{~d}^{-1}\right)$. Thus, the local main emitter differs, but in both locations, it can be traced back to the paper industry located there. In general, the booming online trade and the associated increase in the volume of packaging have led to an increase in the production capacity of the paper producers in the catchment area (Kaleß et al., 2020). Therefore, this explains higher loads and increased detection of substances from paper production in the river water.

2-Methylthiobenzothiazole was also detected more frequently in both recent campaigns. In 2004, it was only found at sampling locations close to the mouth and below the quantification limit. In 2015 and 2020, the WWTP Düren was the main emitter resulting in loads of $40 \mathrm{~g} \mathrm{~d}^{-1}$ and $42 \mathrm{~g} \mathrm{~d}^{-1}$, respectively. In 2015 , however, the inflow of the Wurm also led to a high load $\left(63 \mathrm{~g} \mathrm{~d}^{-1}\right)$, which was not the case in 2020 .

Moreover, the substances DMPA, phenyl isocyanate, and oxcarbazepine have only been detected in 2020. They all occur only downstream of the WWTP Düren and are thus discharged by industrial (DMPA, phenyl isocyanate) and municipal (oxcarbazepine) wastewater effluents there. DMPA, oxcarbazepine, and phenyl isocyanate occurred with loads of $24 \mathrm{~g} \mathrm{~d}^{-1}, 17 \mathrm{~g} \mathrm{~d}^{-1}$, and $129 \mathrm{~g} \mathrm{~d}^{-1}$, respectively. Oxcarbazepine was first approved in Germany in 2000 (Flesch, 2004). However, studies on tolerability only followed in subsequent years, so the detection in 2020 may be due to an increased usage of this pharmaceutical (Freidel et al., 2007; Steinhoff, 2009).

Looking specifically at the courses of the emission profiles and not just the loads, the greatest variations were noticeable for the influence of the Wurm tributary. Although the largest WWTP in the catchment area discharges into it, the inflow of the Wurm did not lead to any significant increase in concentration and load in 2020 for most of the identified substances. In 2004 and 2015, this tributary had the character of a main point source. For example, when considering the entire emission profile, the inputs of 4-oxoisophorone were highest at this location, with loads of $204 \mathrm{~g} \mathrm{~d}^{-1}$ in 2004 and $57 \mathrm{~g} \mathrm{~d}^{-1}$ in 2015. As shown in Fig. 5, this influence was no longer evident in 2020.
Fig. 5 Temporal and spatial distribution of 4-oxoisophorone loads ( $\mathrm{g}$ $\mathrm{d}^{-1}$ ) over the entire river course with peak values at the confluence of the Wurm tributary, into which the effluents of the wastewater treatment plant in Aachen are discharged. This influence declined from 2004 (gray) to 2015 (orange) and is no longer discernible in 2020 (blue). The sampling sites are indicated in Fig. 1

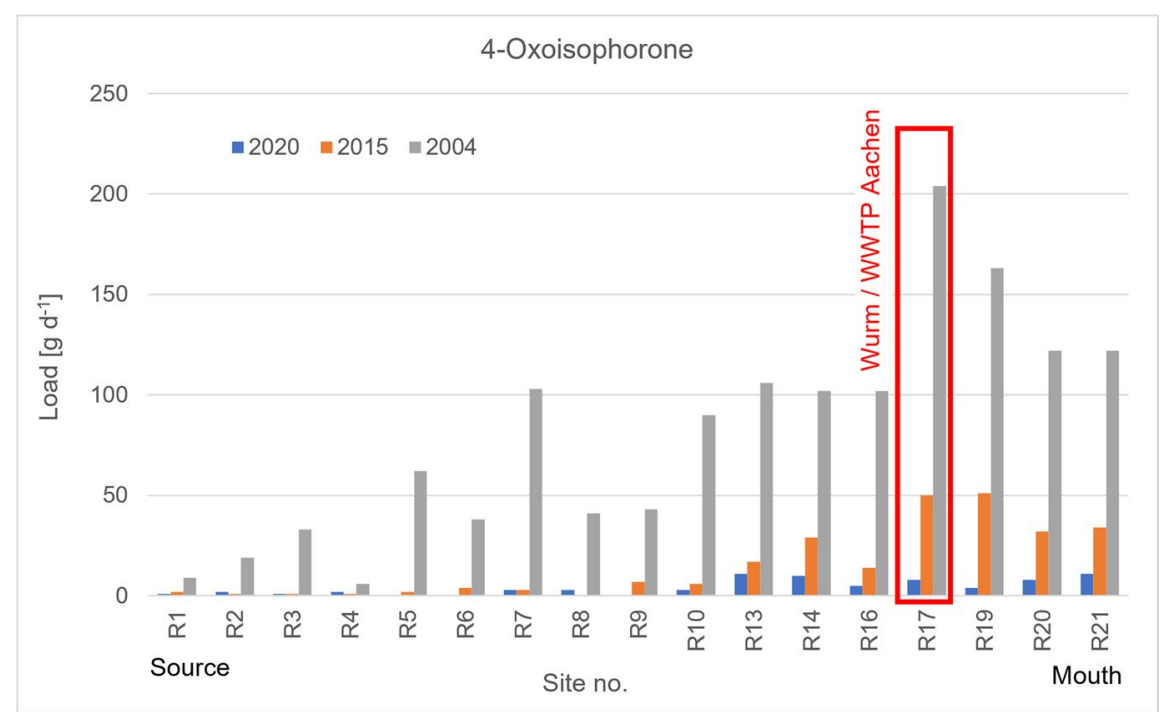


However, the detected concentrations and loads of 4-oxoisophorone were generally significantly lower in 2020 (max. $12 \mathrm{~g} \mathrm{~d}^{-1}$ ), but its ubiquitous presence remained. A reason for the reduced influence of the Wurm could be the large-scale ozone plant at the WWTP Aachen, which has been in operation since 2018. Initial investigations as well as the previous pilot operation already showed promising results regarding the elimination of trace substances (on average $80 \%$ ) and the formation of transformation products (Brückner et al., 2018). However, a final report on the effects and optimisation of this plant in operation is still pending.

It is important to include such concrete measures in consideration of organic contamination as well as temporal and spatial changes per se because the occurrence of substances in a river system depends on many different factors and parameters. Only with such detailed consideration of changing emission profiles and behaviors, a holistic assessment and evaluation is possible.

\section{Conclusions}

GC/MS non-target screenings revealed the presence of a wide spectrum of low-molecular-weight organic compounds showing a high structural diversity as well as a high diversity in environmental behaviors. Many contaminants are of anthropogenic origin and used as, e.g., pharmaceuticals, personal care products, or in industrial processes. Based on the emission profiles, initial assessments are made about the stability and environmental behavior of the contaminants. These largely coincide with previously published research results. For some substances, however, further investigations are still necessary, as they have rarely been considered as environmentally relevant contaminants (e.g., AIBN/TMSN, BHT-quinone, oxcarbazepine, or methylphenylsulfone).

Their environmental pathways were mainly traced back to effluents of wastewater treatment plants. Especially the treatment plant in Düren showed a high input and influence on the chemical diversity in the river system as the diversity and loads of organic contaminants are clearly higher downstream of this WWTP than in the river upstream. However, this can be attributed to the diverse influents of the wastewater treatment plant which collects municipal as well as industrial wastewaters. The paper industry plays a major role here so that corresponding contaminants as TMDD or diphenoxyethane were also detected, partly with very high loads. Interestingly, the effluents of the even larger wastewater treatment plant in Aachen (which discharges into the Wurm tributary) no longer have a major impact on the contamination of the Rur river in 2020 compared to earlier investigations (2004 and 2015). This is probably due to an improved removal performance from a new ozonation system. In general, many decreases in loads and concentrations were observed over the three sampling campaigns and the corresponding 16-year time window. However, higher loads were also detected in individual cases, which indicate increased consumption (e.g., in the paper industry). Over the years, the overall composition of the contamination load in the Rur river has changed slightly, but nevertheless, the high chemical diversity and structural variety remained. This also shows that regular surveys of river systems are necessary to identify current contamination and take appropriate action if necessary.

Overall, a detailed consideration such as that undertaken in this study is necessary as the occurrence of substances in a river system depends on many different factors. For a holistic assessment of environmental behavior, however, not only the sampling locations and associated development of emission profiles over the course of the river must be considered but also temporal variations as well as associated measures (e.g., technical and technological development of WWTPs or bans on certain substances). Such a multi-parameter scenario of changing emission profiles and environmental behavior provides an important basis for the mitigation and reduction of organic pollutants in our environment.

Acknowledgements This study is supported institutionally by the Chair of Physical Geography and Geoecology and the Institute of Hydraulic Engineering and Water Resources Management, RWTH Aachen University. Special thanks to Gerrit Grannemann and Pascal Johnen for their support in the frame of their theses. In addition, C.S. thanks the RWTH Scholarships for Doctoral Students.

Funding Open Access funding enabled and organized by Projekt DEAL. C.S. was financially supported by the RWTH Aachen University Scholarships for Doctoral Students. 
Data availability All data generated or analyzed during this study are included in this published article and its supplementary information files.

Code Availability Not applicable.

\section{Declarations}

Conflict of Interest The authors declare no competing interests.

Open Access This article is licensed under a Creative Commons Attribution 4.0 International License, which permits use, sharing, adaptation, distribution and reproduction in any medium or format, as long as you give appropriate credit to the original author(s) and the source, provide a link to the Creative Commons licence, and indicate if changes were made. The images or other third party material in this article are included in the article's Creative Commons licence, unless indicated otherwise in a credit line to the material. If material is not included in the article's Creative Commons licence and your intended use is not permitted by statutory regulation or exceeds the permitted use, you will need to obtain permission directly from the copyright holder. To view a copy of this licence, visit http://creativecommons.org/licenses/by/4.0/.

\section{References}

Aronson, D., Weeks, J., Meylan, B., Guiney, P., \& Howard, P. (2012). Environmental release, environmental concentrations, and ecological risk of N, N-Diethyl-m-toluamide (DEET). Integrated Environmental Assessment and Management, 8(1), 135-166. https://doi.org/10.1002/ieam. 271

Asimakopoulos, A., Ajibola, A., Kannan, K., \& Thomaidis, N. (2013). Occurrence and removal efficiencies of benzotriazoles and benzothiazoles in a wastewater treatment plant in Greece. Science of the Total Environment, 452453, 163-171. https://doi.org/10.1016/j.scitotenv.2013. 02.041

Benotti, M., Trenholm, R., Vanderford, B., Holady, J., Stanford, B., \& Snyder, S. (2009). Pharmaceuticals and endocrine disrupting compounds in U.S. drinking water. Environmental Science \& Technology, 43(3), 597-603. https://doi.org/10.1021/es801845a

Bernhardt, E., Rosi, E., \& Gessner, M. (2017). Synthetic chemicals as agents of global change. Frontiers in Ecology and the Environment, 15(2), 84-90. https://doi.org/10. $1002 /$ fee. 1450

Bolek, R., \& Kümmerer, K. (2010). Fate and effects of little investigated scents in the aquatic environment. In D. Fatta-Kassinos, K. Bester, \& K. Kümmerer (Eds.), Xenobiotics in the Urban Water Cycle (pp. 87-100). Springer.

Bollmann, U., Möller, A., Xie, Z., Ebinghaus, R., \& Einax, J. (2012). Occurrence and fate of organophosphorus flame retardants and plasticizers in coastal and marine surface waters. Water Research, 46(2), 531-538. https://doi.org/ 10.1016/j.watres.2011.11.028
Botalova, O., Schwarzbauer, J., \& al Sandouk, N. (2011). Identification and chemical characterization of specific organic indicators in the effluents from chemical production sites. Water Research, 45(12), 3653-3664. https:// doi.org/10.1016/j.watres.2011.04.012

Botalova, O., Schwarzbauer, J., Frauenrath, T., \& Dsikowitzky, L. (2009). Identification and chemical characterization of specific organic constituents of petrochemical effluents. Water Research, 43(15), 3797-3812. https://doi.org/10. 1016/j.watres.2009.06.006

Brand, N., Mailhot, G., \& Bolte, M. (1997). Degradation and photodegradation of tetraacetylethylenediamine (TAED) in the presence of iron (III) in aqueous solution. Chemosphere, 34(12), 2637-2648. https://doi.org/10.1016/ S0045-6535(97)00107-0

Brezina, E., Prasse, C., Meyer, J., Mückter, H., \& Ternes, T. (2017). Investigation and risk evaluation of the occurrence of carbamazepine, oxcarbazepine, their human metabolites and transformation products in the urban water cycle. Environmental Pollution, 225, 261-269. https://doi.org/10.1016/j.envpol.2016.10.106

Brückner, I., Klaer, K., Schiwy, S., Kirchner, K., HammersWirtz, M., \& Müller, Y., et al. (2018). Abschlussbericht der Phase 1 des Forschungsvorhabens Demonstrationsvorhaben Ozonung des Abwassers auf der Kläranlage Aachen-Soers (DemO3AC). Gerichtet an das MULNV $N R W$. Düren.

Ccanccapa-Cartagena, A., Pico, Y., Ortiz, X., \& Reiner, E. (2019). Suspect, non-target and target screening of emerging pollutants using data independent acquisition: Assessment of a Mediterranean River basin. Science of the Total Environment, 687, 355-368. https://doi.org/10. 1016/j.scitotenv.2019.06.057

Cerniglia, C. (1993). Biodegradation of polycyclic aromatic hydrocarbons. Current Opinion in Biotechnology, 4(3), 331-338. https://doi.org/10.1016/0958-1669(93)90104-5

Clara, M., Strenn, B., \& Kreuzinger, N. (2004). Carbamazepine as a possible anthropogenic marker in the aquatic environment: Investigations on the behaviour of Carbamazepine in wastewater treatment and during groundwater infiltration. Water Research, 38(4), 947-954. https://doi. org/10.1016/j.watres.2003.10.058

Cristale, J., Katsoyiannis, A., Sweetman, A., Jones, K., \& Lacorte, S. (2013). Occurrence and risk assessment of organophosphorus and brominated flame retardants in the River Aire (UK). Environmental Pollution, 179, 194200. https://doi.org/10.1016/j.envpol.2013.04.001

Dey, S., Bano, F., \& Malik, A. (2019). Pharmaceuticals and personal care product (PPCP) contamination-A global discharge inventory. In M. N. V. Prasad, M. Vithanage, \& A. Kapley (Eds.), Pharmaceuticals and Personal Care Products: Waste Management and Treatment Technology (pp. 1-26). Elsevier.

Dsikowitzky, L., Botalova, O., al Sandouk-Lincke, N., \& Schwarzbauer, J. (2014a). Identification of specific organic contaminants in different units of a chemical production site. Environmental Science: Processes \& Impacts, 16(7), 1779-1789. https://doi.org/10.1039/ $\mathrm{c} 4 \mathrm{em} 00034 \mathrm{j}$

Dsikowitzky, L., Botalova, O., Illgut, S., Bosowski, S., \& Schwarzbauer, J. (2015). Identification of characteristic 
organic contaminants in wastewaters from modern paper production sites and subsequent tracing in a river. Journal of Hazardous Materials, 300, 254-262. https://doi. org/10.1016/j.jhazmat.2015.07.001

Dsikowitzky, L., Dwiyitno, Heruwati, E., Ariyani, F., Irianto, H., \& Schwarzbauer, J. (2014b). Exceptionally high concentrations of the insect repellent N,N-diethyl-mtoluamide (DEET) in surface waters from Jakarta, Indonesia. Environmental Chemistry Letters, 12(3), 407-411. https://doi.org/10.1007/s10311-014-0462-6

Dsikowitzky, L., Hagemann, L., Dwiyitno, Ariyani, F., Irianto, H., \& Schwarzbauer, J. (2017). Complex organic pollutant mixtures originating from industrial and municipal emissions in surface waters of the megacity Jakarta - An example of a water pollution problem in emerging economies. Environmental Science and Pollution Research, 24(35), 27539-27552. https://doi.org/10.1007/ s11356-017-0164-2

Dsikowitzky, L., Schwarzbauer, J., Kronimus, A., \& Littke, R. (2004a). The anthropogenic contribution to the organic load of the Lippe River (Germany). Part I: Qualitative characterisation of low-molecular weight organic compounds. Chemosphere, 57(10), 1275-1288. https://doi. org/10.1016/j.chemosphere.2004.08.052

Dsikowitzky, L., Schwarzbauer, J., \& Littke, R. (2002). Distribution of polycyclic musks in water and particulate matter of the Lippe River (Germany). Organic Geochemistry, 33(12), 1747-1758. https://doi.org/10.1016/S01466380(02)00115-8

Dsikowitzky, L., Schwarzbauer, J., \& Littke, R. (2004b). The anthropogenic contribution to the organic load of the Lippe River (Germany). Part II: Quantification of specific organic contaminants. Chemosphere, 57(10), 1289-1300. https://doi.org/10.1016/j.chemo sphere.2004.08.053

Durán-Álvarez, J., Prado, B., González, D., Sánchez, Y., \& Jiménez-Cisneros, B. (2015). Environmental fate of naproxen, carbamazepine and triclosan in wastewater, surface water and wastewater irrigated soil - Results of laboratory scale experiments. Science of the Total Environment, 538, 350-362. https://doi.org/10.1016/j.scito tenv.2015.08.028

European Commission. (2003). Directive 2003/15/EC of the European Parliament and of the Council of 27 February 2003 amending Council Directive 76/768/EEC on the approximation of the laws of the Member States relating to cosmetic products. Official Journal of the European Union, L66, 26-35.

Felczak, A., Bernat, P., Różalska, S., \& Lisowska, K. (2016). Quinoline biodegradation by filamentous fungus Cunninghamella elegans and adaptive modifications of the fungal membrane composition. Environmental Science and Pollution Research, 23(9), 8872-8880. https://doi. org/10.1007/s11356-016-6116-4

Fiehn, O., Reemtsma, T., \& Jekel, M. (1994). Extraction and analysis of various benzothiazoles from industrial wastewater. Analytica Chimica Acta, 295(3), 297-305. https://doi.org/10. 1016/0003-2670(94)80235-1

Flesch, G. (2004). Overview of the clinical pharmacokinetics of oxcarbazepine. Clinical Drug Investigation, 24(4),
185-203. https://doi.org/10.2165/00044011-20042 4040-00001

Freidel, M., Krause, E., Kuhn, K., Peper, R., \& Vogel, H. (2007). Oxcarbazepin in der Epilepsietherapie. Fortschritte Der Neurologie-Psychiatrie, 75(2), 100106. https://doi.org/10.1055/s-2006-932218

Fromme, H., Küchler, T., Otto, T., Pilz, K., Müller, J., \& Wenzel, A. (2002). Occurrence of phthalates and bisphenol A and $\mathrm{F}$ in the environment. Water Research, 36(6), 14291438. https://doi.org/10.1016/S0043-1354(01)00367-0

Godayol, A., Besalú, E., Anticó, E., \& Sanchez, J. (2015). Monitoring of sixteen fragrance allergens and two polycyclic musks in wastewater treatment plants by solid phase microextraction coupled to gas chromatography. Chemosphere, 119, 363-370. https://doi.org/10.1016/j. chemosphere.2014.06.072

Gómez, M., Herrera, S., Solé, D., García-Calvo, E., \& Fernández-Alba, A. (2012). Spatio-temporal evaluation of organic contaminants and their transformation products along a river basin affected by urban, agricultural and industrial pollution. Science of the Total Environment, 420, 134-145. https://doi.org/10.1016/j.scitotenv. 2012.01.029

Gorga, M., Insa, S., Petrovic, M., \& Barceló, D. (2015). Occurrence and spatial distribution of EDCs and related compounds in waters and sediments of Iberian rivers. Science of the Total Environment, 503-504, 69-86. https://doi.org/10.1016/j.scitotenv.2014.06.037

Grigoriadou, A., \& Schwarzbauer, J. (2011). Non-target screening of organic contaminants in sediments from the industrial coastal area of Kavala City (NE Greece). Water, Air, \& Soil Pollution, 214(1-4), 623-643. https://doi.org/10.1007/S11270-010-0451-8

Grigoriadou, A., Schwarzbauer, J., \& Georgakopoulos, A. (2008). Molecular indicators for pollution source identification in marine and terrestrial water of the industrial area of Kavala city, North Greece. Environmental Pollution, 151(1), 231-242. https://doi.org/10.1016/j. envpol.2007.01.053

Guedez, A., \& Püttmann, W. (2011). Occurrence and fate of TMDD in wastewater treatment plants in Germany. Water Research, 45(16), 5313-5322. https://doi.org/10. 1016/j.watres.2011.07.038

Heim, S., \& Schwarzbauer, J. (2013). Pollution history revealed by sedimentary records: A review. Environmental Chemistry Letters, 11(3), 255-270. https://doi. org/10.1007/s 10311-013-0409-3

Heudorf, U., Mersch-Sundermann, V., \& Angerer, J. (2007). Phthalates: Toxicology and exposure. International Journal of Hygiene and Environmental Health, 210(5), 623-634. https://doi.org/10.1016/j.ijheh.2007.07.011

Hidalgo-Serrano, M., Borrull, F., Marcé, R., \& Pocurull, E. (2019). Presence of benzotriazoles, benzothiazoles and benzenesulfonamides in surface water samples by liquid chromatography coupled to high-resolution mass spectrometry. Separation Science plus, 2(3), 72-80. https://doi.org/10.1002/sscp.201800140

Holmdahl, M. (1998). Xylocain (lidocaine, lignocaine), its discovery and Gordh's contribution to its clinical use. Acta Anaesthesiologica Scandinavica, 113, 8-12. https://doi.org/10.1111/j.1399-6576.1998.tb04979.x 
Houtman, C. (2010). Emerging contaminants in surface waters and their relevance for the production of drinking water in Europe. Journal of Integrative Environmental Sciences, 7(4), 271-295. https://doi.org/10. 1080/1943815X.2010.511648

Huang, B., Lei, C., Wei, C., \& Zeng, G. (2014). Chlorinated volatile organic compounds (Cl-VOCs) in environment - Sources, potential human health impacts, and current remediation technologies. Environment International, 71, 118-138. https://doi.org/10.1016/j.envint.2014.06.013

Hughes, S., Kay, P., \& Brown, L. (2013). Global synthesis and critical evaluation of pharmaceutical data sets collected from river systems. Environmental Science \& Technology, 47(2), 661-677. https://doi.org/10.1021/es3030148

IT.NRW (2019, July 31). Wasserversorgung nach Eigengewinnung, Fremdbezug und Wasserabgabe an Letztverbraucher. Landesbetrieb Information und Technik Nordrhein-Westfalen. Retrieved August 24, 2021, from https:// www.it.nrw/statistik/eckdaten/wasserversorgung-nacheigengewinnung-fremdbezug-und-wasserabgabe-letzt verbraucher

Johannsen, F., \& Levinskas, G. (1986). Subchronic toxicity of tetramethylsuccinonitrile. Fundamental and Applied Toxicology, 7(1), 41-48. https://doi.org/10.1016/02720590(86)90195-8

Johnstone, A., Mack, C., Valdez, M., Shafer, T., LoPachin, R., Herr, D., et al. (2020). Acute in vitro effects on embryonic rat dorsal root ganglion (DRG) cultures by in silico predicted neurotoxic chemicals: Evaluations on cytotoxicity, neurite length, and neurophysiology. Toxicology in Vitro, 69, 104989. https://doi.org/10.1016/j.tiv.2020. 104989

Jüttner, F. (1999). Efficacy of bank filtration for the removal of fragrance compounds and aromatic hydrocarbons. Water Science and Technology, 40(6), 123-128. https://doi.org/ 10.1016/S0273-1223(99)00547-8

Kaiser, E., Prasse, C., Wagner, M., Bröder, K., \& Ternes, T. (2014). Transformation of oxcarbazepine and human metabolites of carbamazepine and oxcarbazepine in wastewater treatment and sand filters. Environmental Science \& Technology, 48(17), 10208-10216. https://doi. org/10.1021/es5024493

Kaleß, M., Reichert, J., \& Demny, G. (2020). Value Engineering als innovativer Lösungsansatz am Beispiel der Kläranlage Düren. Wiener Mitteilungen, 252, 35-50.

Kim, U.-J., \& Kannan, K. (2018). Occurrence and distribution of organophosphate flame retardants/plasticizers in surface waters, tap water, and rainwater: Implications for human exposure. Environmental Science \& Technology, 52(10), 5625-5633. https://doi.org/10.1021/acs.est. $8 \mathrm{~b} 00727$

Kim, U.-J., Oh, J., \& Kannan, K. (2017). Occurrence, removal, and environmental emission of organophosphate flame retardants/plasticizers in a wastewater treatment plant in New York State. Environmental Science \& Technology, 51(14), 7872-7880. https://doi.org/10.1021/acs.est. $7 \mathrm{~b} 02035$

Klaschka, U., von der Ohe, P., Bschorer, A., Krezmer, S., Sengl, M., \& Letzel, M. (2013). Occurrences and potential risks of 16 fragrances in five German sewage treatment plants and their receiving waters. Environmental
Science and Pollution Research, 20(4), 2456-2471. https://doi.org/10.1007/s11356-012-1120-9

Kloepfer, A., Jekel, M., \& Reemtsma, T. (2004). Determination of benzothiazoles from complex aqueous samples by liquid chromatography-mass spectrometry following solidphase extraction. Journal of Chromatography A, 1058(12), 81-88. https://doi.org/10.1016/j.chroma.2004.08.081

Köppe, T., Jewell, K., Dietrich, C., Wick, A., \& Ternes, T. (2020). Application of a non-target workflow for the identification of specific contaminants using the example of the Nidda river basin. Water Research, 178, 115703. https://doi.org/10.1016/j.watres.2020.115703

Leclercq, M., Mathieu, O., Gomez, E., Casellas, C., Fenet, H., \& Hillaire-Buys, D. (2009). Presence and fate of carbamazepine, oxcarbazepine, and seven of their metabolites at wastewater treatment plants. Archives of Environmental Contamination and Toxicology, 56(3), 408-415. https://doi.org/10.1007/s00244-008-9202-X

Lin, C., Nguyen, K., Vu, C., Senoro, D., \& Villanueva, M. (2017). Contamination levels and potential sources of organic pollution in an Asian river. Water Science and Technology, 76(9-10), 2434-2444. https://doi.org/10. 2166/wst.2017.419

Liu, R., \& Mabury, S. (2020). Synthetic phenolic antioxidants: A review of environmental occurrence, fate, human exposure, and toxicity. Environmental Science \& Technology, 54(19), 11706-11719. https://doi.org/ 10.1021/acs.est.0c05077

Lorenzo, M., Campo, J., \& Picó, Y. (2018). Analytical challenges to determine emerging persistent organic pollutants in aquatic ecosystems. TrAC Trends in Analytical Chemistry, 103, 137-155. https://doi.org/10.1016/j.trac.2018.04. 003

Ma, B.-J., Peng, H., \& Liu, J.-K. (2006). Monitoring of BHTquinone and BHT-CHO in the gas of capsules of Asclepias physocarpa. Zeitschrift Fur Naturforschung C, 61(56), 458-460. https://doi.org/10.1515/znc-2006-5-625

Malow, M., Wehrstedt, K.-D., \& Manolov, M. (2015). Thermal decomposition of AIBN Part A: Decomposition in real scale packages and SADT determination. Thermochimica Acta, 621, 1-5. https://doi.org/10.1016/j.tca.2015.06.013

Matamoros, V., Arias, C., Nguyen, L., Salvadó, V., \& Brix, H. (2012). Occurrence and behavior of emerging contaminants in surface water and a restored wetland. Chemosphere, 88(9), 1083-1089. https://doi.org/10.1016/j. chemosphere.2012.04.048

Mohapatra, D., \& Kirpalani, D. (2019). Advancement in treatment of wastewater: Fate of emerging contaminants. The Canadian Journal of Chemical Engineering, 97(10), 2621-2631. https://doi.org/10.1002/cjce.23533

Moldovan, Z., Marincas, O., Povar, I., Lupascu, T., Longree, P., Rota, J., et al. (2018). Environmental exposure of anthropogenic micropollutants in the Prut River at the Romanian-Moldavian border: A snapshot in the lower Danube river basin. Environmental Science and Pollution Research, 25(31), 31040-31050. https://doi.org/10.1007/ s11356-018-3025-8

Morin-Crini, N., Lichtfouse, E., \& Crini, G. (Eds.). (2021). Emerging Contaminants (Vol. 1). Springer International Publishing. 
Nagai, F., Ushiyama, K., \& Kano, I. (1993). DNA cleavage by metabolites of butylated hydroxytoluene. Archives of Toxicology, 67(8), 552-557. https://doi.org/10.1007/ BF01969268

Net, S., Sempéré, R., Delmont, A., Paluselli, A., \& Ouddane, B. (2015). Occurrence, fate, behavior and ecotoxicological state of phthalates in different environmental matrices. Environmental Science \& Technology, 49(7), 40194035. https://doi.org/10.1021/es505233b

Neuwoehner, J., Reineke, A.-K., Hollender, J., \& Eisentraeger, A. (2009). Ecotoxicity of quinoline and hydroxylated derivatives and their occurrence in groundwater of a tar-contaminated field site. Ecotoxicology and Environmental Safety, 72(3), 819-827. https://doi.org/10.1016/j. ecoenv.2008.04.012

Pantelaki, I., \& Voutsa, D. (2019). Organophosphate flame retardants (OPFRs): A review on analytical methods and occurrence in wastewater and aquatic environment. Science of the Total Environment, 649, 247-263. https://doi. org/10.1016/j.scitotenv.2018.08.286

Patel, M., Kumar, R., Kishor, K., Mlsna, T., Pittman, C., \& Mohan, D. (2019). Pharmaceuticals of emerging concern in aquatic systems: Chemistry, occurrence, effects, and removal methods. Chemical Reviews, 119(6), 35103673. https://doi.org/10.1021/acs.chemrev.8b00299

Petrovic, M. (2003). Analysis and removal of emerging contaminants in wastewater and drinking water. TrAC Trends in Analytical Chemistry, 22(10), 685-696. https://doi. org/10.1016/S0165-9936(03)01105-1

Petrovic, M., Sabater, S., Elosegi, A., \& Barceló, D. (2016). Emerging Contaminants in River Ecosystems: Springer International Publishing

Reemtsma, T., Fiehn, O., Kalnowski, G., \& Jekel, M. (1995). Microbial transformations and biological effects of fungicide-derived benzothiazoles determined in industrial wastewater. Environmental Science \& Technology, 29(2), 478-485. https://doi.org/10.1021/es00002a025

Reemtsma, T., Quintana, J., Rodil, R., Garcı'a-López, M., \& Rodrı'guez, I. (2008). Organophosphorus flame retardants and plasticizers in water and air I. Occurrence and fate. TrAC Trends in Analytical Chemistry, 27(9), 727737. https://doi.org/10.1016/j.trac.2008.07.002

Reemtsma, T., Weiss, S., Mueller, J., Petrovic, M., González, S., Barcelo, D., et al. (2006). Polar pollutants entry into the water cycle by municipal wastewater: A European perspective. Environmental Science \& Technology, 40(17), 5451-5458. https://doi.org/10.1021/es060908a

Regnery, J., \& Püttmann, W. (2010). Occurrence and fate of organophosphorus flame retardants and plasticizers in urban and remote surface waters in Germany. Water Research, 44(14), 4097-4104. https://doi.org/10.1016/j. watres.2010.05.024

Rúa-Gómez, P., \& Püttmann, W. (2012a). Impact of wastewater treatment plant discharge of lidocaine, tramadol, venlafaxine and their metabolites on the quality of surface waters and groundwater. Journal of Environmental Monitoring, 14(5), 1391-1399. https://doi.org/10.1039/ c2em10950f

Rúa-Gómez, P., \& Püttmann, W. (2012b). Occurrence and removal of lidocaine, tramadol, venlafaxine, and their metabolites in German wastewater treatment plants.
Environmental Science and Pollution Research, 19(3), 689-699. https://doi.org/10.1007/s11356-011-0614-1

Ruff, M., Mueller, M., Loos, M., \& Singer, H. (2015). Quantitative target and systematic non-target analysis of polar organic micro-pollutants along the river Rhine using high-resolution mass-spectrometry - Identification of unknown sources and compounds. Water Research, 87, 145-154. https://doi.org/10.1016/j.watres.2015.09.017

Safe, S. (1994). Polychlorinated biphenyls (PCBs): Environmental impact, biochemical and toxic responses, and implications for risk assessment. Critical Reviews in Toxicology, 24(2), 87-149. https://doi.org/10.3109/10408 449409049308

Schäfer, R., von der Ohe, P., Kühne, R., Schuüuürmann, G., \& Liess, M. (2011). Occurrence and toxicity of 331 organic pollutants in large rivers of north Germany over a decade (1994 to 2004). Environmental Science \& Technology, 45(14), 6167-6174. https://doi.org/10.1021/es2013006

Schröder, F. (1995). Monitoring von Tensiden in kritisch belasteten Fließgewässern/ Concentrations of anionic surfactants in receiving riverine water. Tenside Surfactants Detergents, 32(6), 492-497. https://doi.org/10. 1515/tsd-1995-320613

Schulze, C., \& Matthies, M. (2001). Georeferenced aquatic fate simulation of cleaning agent and detergent ingredients in the river Rur catchment (Germany). Science of the Total Environment, 280(1-3), 55-77. https://doi. org/10.1016/S0048-9697(01)00814-2

Schwarzbauer, J. (2006). Organic contaminants in riverine and groundwater systems: Springer-Verlag Berlin Heidelberg

Schwarzbauer, J., \& Heim, S. (2005). Lipophilic organic contaminants in the Rhine river, Germany. Water Research, 39(19), 4735-4748. https://doi.org/10.1016/j.watres. 2005.09.029

Schwarzbauer, J., \& Ricking, M. (2010). Non-target screening analysis of river water as compound-related base for monitoring measures. Environmental Science and Pollution Research, 17(4), 934-947. https://doi.org/10.1007/ s11356-009-0269-3

Schwientek, M., Guillet, G., Rügner, H., Kuch, B., \& Grathwohl, P. (2016). A high-precision sampling scheme to assess persistence and transport characteristics of micropollutants in rivers. Science of the Total Environment, 540, 444-454. https://doi.org/10.1016/j.scitotenv.2015. 07.135

Staatliches Umweltamt Aachen (2005). Ergebnisbericht Rur und südliche sonstige Maaszuflüsse. Bearbeitungsgebiet Maas-Deutschland (Süd). Wasserrahmenrichtlinie in NRW, Bestandsaufnahme. Düsseldorf.

Staples, C., Peterson, D., Parkerton, T., \& Adams, W. (1997). The environmental fate of phthalate esters: A literature review. Chemosphere, 35(4), 667-749. https://doi.org/10. 1016/S0045-6535(97)00195-1

Steinhoff, B. (2009). Verzögert freigesetztes Oxcarbazepin - Überblick und klinische Erfahrungen. Zeitschrift für Epileptologie, 22(1), 2-8. https://doi.org/10.1007/ s10309-009-0017-1

Sýkora, V., Pitter, P., Bittnerová, I., \& Lederer, T. (2001). Biodegradability of ethylenediamine-based complexing agents. Water Research, 35(8), 2010-2016. https://doi. org/10.1016/S0043-1354(00)00455-3 
Takeshita, A., Igarashi-Migitaka, J., Nishiyama, K., Takahashi, H., Takeuchi, Y., \& Koibuchi, N. (2011). Acetyl tributyl citrate, the most widely used phthalate substitute plasticizer, induces cytochrome p450 3a through steroid and xenobiotic receptor. Toxicological Sciences, 123(2), 460470. https://doi.org/10.1093/toxsci/kfr178

Tang, Y., Yin, M., Yang, W., Li, H., Zhong, Y., Mo, L., et al. (2019). Emerging pollutants in water environment: Occurrence, monitoring, fate, and risk assessment. Water Environment Research, 91(10), 984-991. https://doi.org/ 10.1002/wer.1163

Turusov, V., Rakitsky, V., \& Tomatis, L. (2002). Dichlorodiphenyltrichloroethane (DDT): Ubiquity, persistence, and risks. Environmental Health Perspectives, 110(2), 125128. https://doi.org/10.1289/ehp.02110125

van der Veen, I., \& de Boer, J. (2012). Phosphorus flame retardants: Properties, production, environmental occurrence, toxicity and analysis. Chemosphere, 88(10), 1119-1153. https://doi.org/10.1016/j.chemosphere.2012.03.067

Vulliet, E., Cren-Olivé, C., \& Grenier-Loustalot, M.-F. (2011). Occurrence of pharmaceuticals and hormones in drinking water treated from surface waters. Environmental Chemistry Letters, 9(1), 103-114. https://doi.org/10. 1007/s10311-009-0253-7

Wang, J., Liu, X., \& Lu, J. (2012). Urban river pollution control and remediation. Procedia Environmental Sciences, 13, 1856-1862. https://doi.org/10.1016/j.proenv.2012.01. 179

Wang, R., Tang, J., Xie, Z., Mi, W., Chen, Y., Wolschke, H., et al. (2015). Occurrence and spatial distribution of organophosphate ester flame retardants and plasticizers in 40 rivers draining into the Bohai Sea, north China. Environmental Pollution, 198, 172-178. https://doi.org/ 10.1016/j.envpol.2014.12.037
Wasserverband Eifel-Rur. (2017a). Die Rurtalsperre. Düren. Retrieved July 13, 2021, from https://wver.de/wp-conte nt/uploads/2019/11/Rurtalsperre.pdf

Wasserverband Eifel-Rur. (2017b). Jahresbericht 2016. Düren. Retrieved November 13, 2020, from https://wver.de/jahre sbericht2016/

Weeks, J., Guiney, P., \& Nikiforov, A. (2012). Assessment of the environmental fate and ecotoxicity of N, N-diethylm-toluamide (DEET). Integrated Environmental Assessment and Management, 8(1), 120-134. https://doi.org/10. 1002/ieam. 1246

Wu, Y., Venier, M., \& Hites, R. (2019). Identification of unusual antioxidants in the natural and built environments. Environmental Science \& Technology Letters, 6(8), 443447. https://doi.org/10.1021/acs.estlett.9b00415

Yamashina, M., Sei, Y., Akita, M., \& Yoshizawa, M. (2014). Safe storage of radical initiators within a polyaromatic nanocapsule. Nature Communications, 5, 4662. https:// doi.org/10.1038/ncomms5662

Zhang, S., Zhang, Q., Darisaw, S., Ehie, O., \& Wang, G. (2007). Simultaneous quantification of polycyclic aromatic hydrocarbons (PAHs), polychlorinated biphenyls (PCBs), and pharmaceuticals and personal care products (PPCPs) in Mississippi river water, in New Orleans, Louisiana, USA. Chemosphere, 66(6), 1057-1069. https:// doi.org/10.1016/j.chemosphere.2006.06.067

Publisher's Note Springer Nature remains neutral with regard to jurisdictional claims in published maps and institutional affiliations. 